\title{
Conodont Color Alteration- an Index to Organic Metamorphism
}

By ANITA G. EPSTEIN, JACK B. EPSTEIN, and

LEONARD D. HARRIS

GE OLOGICA L S URVEY PR OFES I O N A L PAPER 995

Experimental and field studies

showing the application of conodont

color alteration to geothermometry, metamorphism, and structural geology

and for assessing hydrocarbon potential

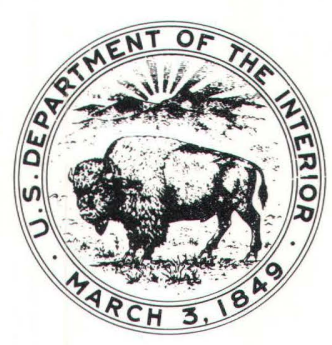

\begin{tabular}{llllll}
\hline UNITED & STATES GOVERNMENT & PRINTING & OFFICE, WASHINGTON & $:$ & 1977
\end{tabular} 


\section{UNITED STATES DEPARTMENT OF THE INTERIOR}

THOMAS S. KLEPPE, Secretary

\section{GEOLOGICAL SURVEY}

V. E. McKelvey, Director

Library of Congress Cataloging in Publication Data

Epstein, Anita G 1937-

Conodont color alteration--an index to organic metamorphism.

(Geological Survey professional paper; 995)

Bibliography: p.

Supt. of Docs. no.: I 19.16:995

1. Conodonts. 2. Paleontology--Paleozoic. 3. Paleontology--Appalachian Mountains. 4. Geological time.

5. Earth temperature. 6. Metamorphism (Geology). I. Epstein, Jack Burton, 1935- joint author. II. Harris, Leonard D., joint author. III. Title. IV. Series: United States. Geological Survey. Professional paper; 995.

QE899.E66 $562 \quad 76-608130$

For sale by the Superintendent of Documents, U.S. Government Printing Office

Washington, D.C. 20402 - Price $\$ 1.10$ (paper cover)

Stock No. 024-001-02856-5 


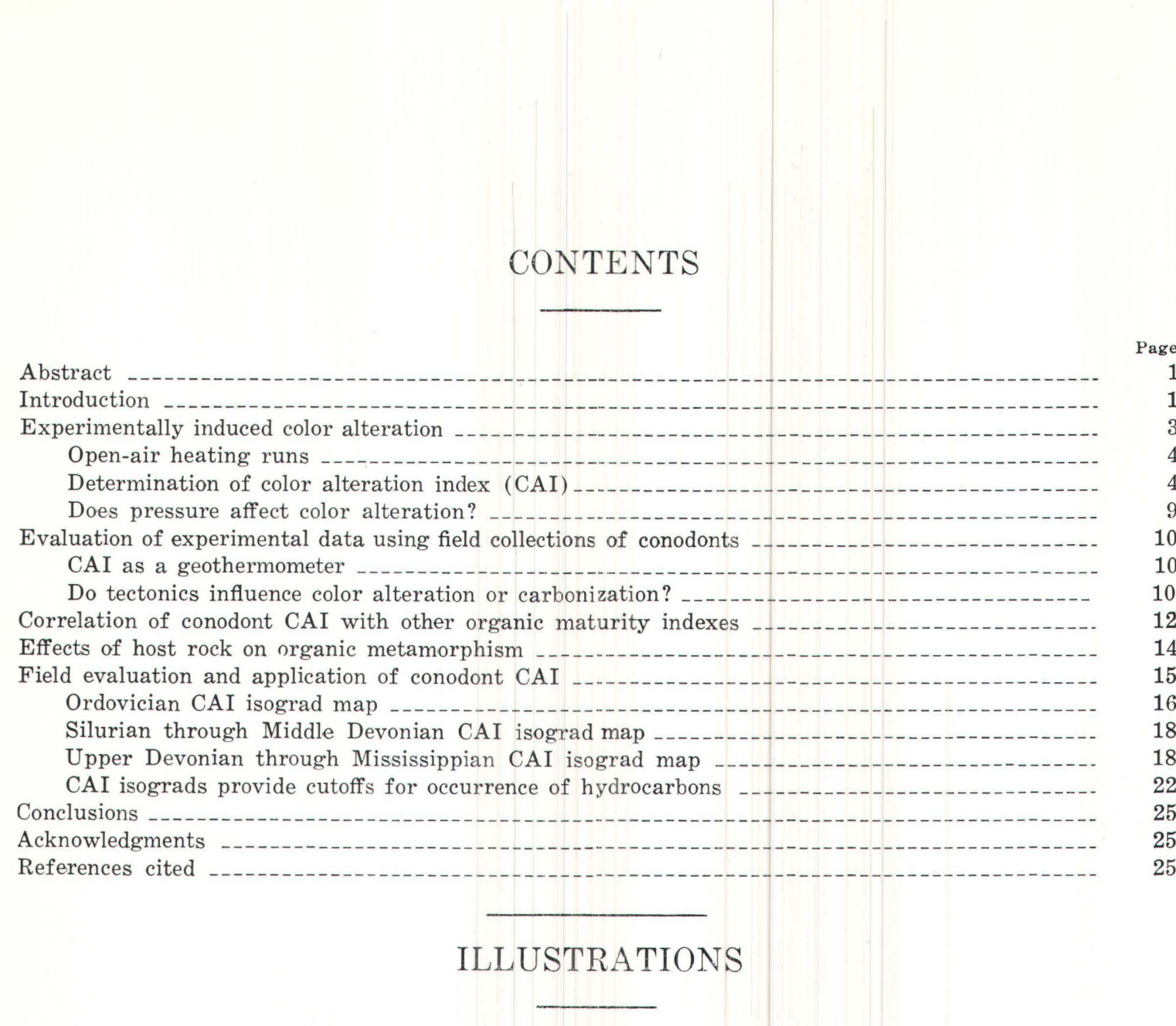

FIGURE 1. Photograph showing conodont elements of diverse form, age, and color

2. Photograph of unaltered conodont elements used in heating experiments

3. Ahrrenius plot of heat-induced, open-air, conodont color alteration data

4. Photograph showing experimentally altered conodonts of all color alteration indexes _..................

5. Chart showing experimentally produced and naturally occurring colors in conodonts and the geologictemperature and fixed-carbon range for each CAI

6. Photograph showing experimentally produced pale-yellow to black to crystal-clear conodonts _......-

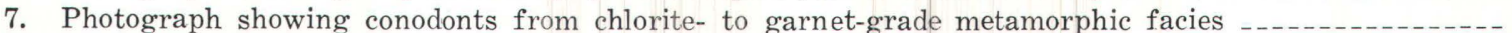

8. Chart showing CAI for conodonts subjected to different pressures and chemical environments while under the same conditions of time and temperature

9. Ahrrenius plot of experimental data showing method of computing maximum host-rock temperature using conodont CAI

10. Map showing selected localities for Early and early Middle Devonian conodonts in part of the Appalachian basin and their known overburden

Page

11. Chart showing correlation of three optical organic metamorphism indexes

12. Chart showing age and thermal range and relative cost of three optical organic metamorphism indexes

13. Map showing CAI isograds for Ordovician conodont localities in the Appalachian basin

14. Maps of the West Virginia-Virginia border area showing isograds superimposed on maximum isotherms for hot springs

15. Map showing major thrust faults and localities for some Middle and Late Ordovician conodonts from eastern Tennessee

16-20. Maps of the Appalachian basin showing:

16. CAI isograds for Silurian through Middle Devonian rocks

17. CAI isograds for Upper Devonian through Mississippian rocks and the eastern limit of oil and gas fields

18. Upper Mississippian CAI isograds superimposed on isopachs for Pennsylvanian rocks 
Figures 16-20. Maps of the Appalachian basin showing-Continued

19. CAI isograds for Ordovician rocks and the eastern limit of oil and gas fields _...........

20. CAI isograds for Silurian through Middle Devonian rocks and the eastern limit of oil and gas fields

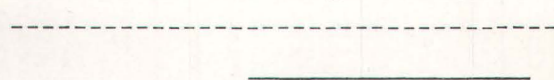

\section{TABLE}

\section{METRIC-ENGLISH EQUIVALENTS}

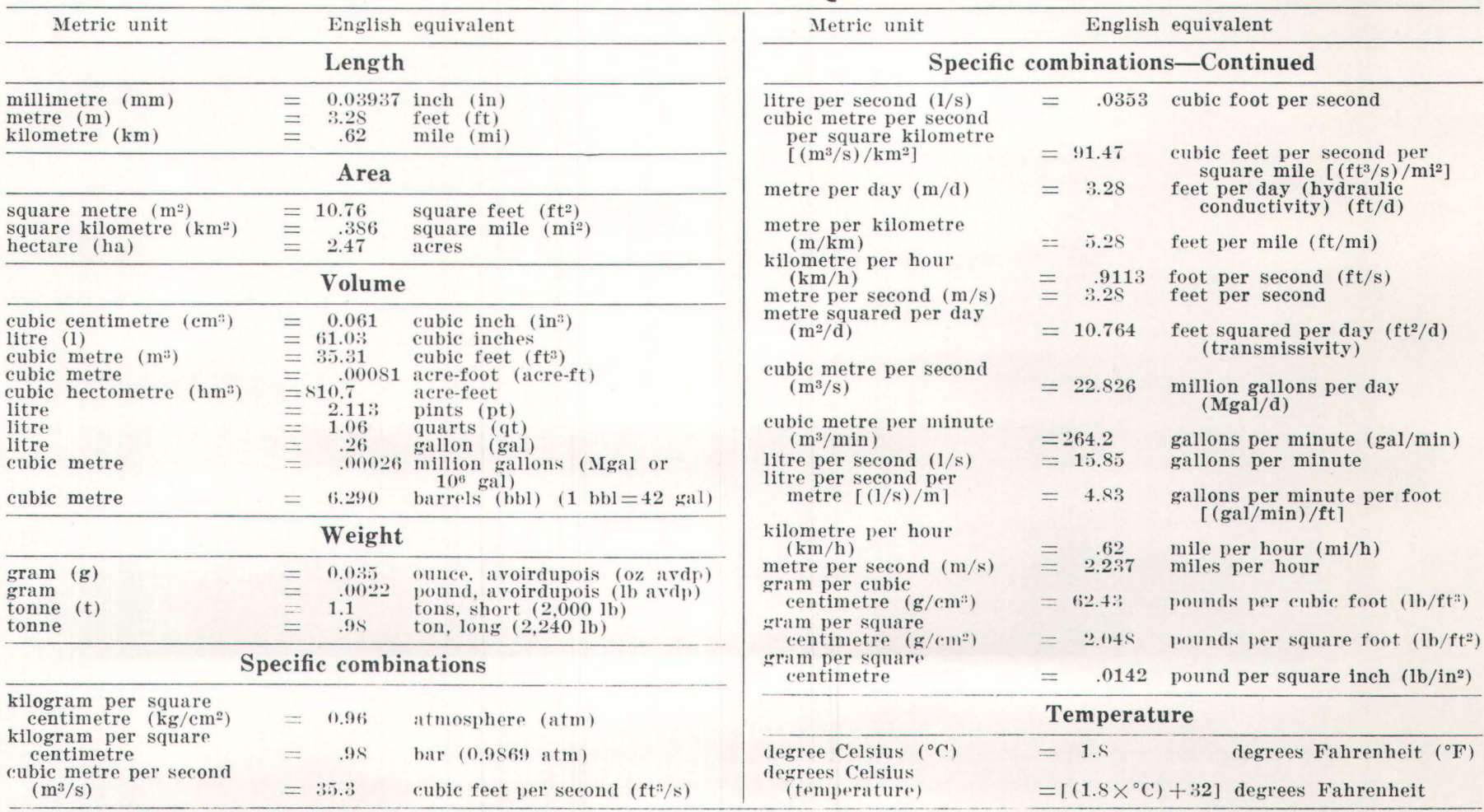




\title{
CONODONT COLOR ALTERATION-AN INDEX TO ORGANIC METAMORPHISM
}

\author{
By Anita G. Epstein, Jack B. Epstein, and Leonard D. Harris
}

\section{ABSTRACT}

Field and laboratory experiments show that color alteration in conodonts is directly related to the depth and duration of burial and the geothermal gradient and correlates with fixed carbon, vitrinite reflectance, palynomorph translucency, and isopach data. Five progressive and irreversible color changes ranging from pale yellow to black are discriminated. Compilation of color alteration index (CAI) maps for limestones of several ages in the Appalachian basin show: (1) a general systematic change from pale yellow $(\mathrm{CAI}=1)$ to black $(\mathrm{CAI}=5)$ from west to east; (2) within a structural belt, older conodonts are darkest; (3) fixed carbon values determined from coals cannot be directly applied to carbonate rocks; (4) several areas of anomalously low CAI values in windows exposing Ordovician rocks within the Blue RidgePiedmont terrane.

All field colors were reproduced by controlled high-temperature $\left(300^{\circ}-600^{\circ} \mathrm{C}\right)$ long-term (10-50 days) runs in open air with and without water. These data show: (1) color alteration of conodonts is time and temperature dependent; (2) the sequence of color change from pale yellow to black found in field collections is the same as that produced by heating alone; (3) upper and lower geologic temperature limits for each CAI determined from a log time versus reciprocal of absolute temperature plot. Experiments at high temperature $\left(550^{\circ} \mathrm{C}\right)$, confined pressure (1 kbar), with and without water, using methane (reducing) and argon (inert), indicate that water in combination with confined pressure retards color alteration.

The color alteration of conodonts is a valuable tool for assessing organic metamorphism because it is a rapid and inexpensive method requiring only standard laboratory techniques and a binocular microscope. Standards can be easily assembled and reproduced. The technique does not provide thermal thresholds for oil generation, but does provide thermal cutoffs for oil, condensate, and dry gas generation. Conodont color alteration begins near the upper thermal limit for the preservation of many palynomorphs. Moreover, conodonts are most abundant and most easily concentrated from marine carbonate rocks in which palynomorphs generally are poorly preserved and in which vitrinite is least abundant and commonly absent.

\section{INTRODUCTION}

In the last two decades, geochemists, coal petrologists, and even micropaleontologists have added an instrumental and chiefly microscopic sophistication to the application of David White's (1915) carbonratio theory. Light transmission and reflectance measurements of palynomorphs and coaly particles, as well as pyrolysis and gas chromatography of organic matter are now standard petroleum and coal industry techniques for assessing organic maturity (see Bostick, 1974; Castaño and Sparks, 1974; Gutjahr, 1966; Martin and others, 1964; Patteisky and others, 1962; Staplin, 1969). This study adds a new index, the conodont, to the growing list of indicators of organic metamorphism. Our technique, moreover, is inexpensive and rapid and is applicable to rock types and to age and thermal ranges that are not readily analyzed by other methods. Until now, we have presented only preliminary evaluations of this technique (Epstein and others, 1974, 1975a, b; Epstein, 1975).

In the last 15-20 years, conodonts have become one of the dominant fossil groups for biostratigraphy and worldwide correlation within most of their geologic range (for example, Sweet and Bergström, 1971). This study increases their use from index fossils to metamorphic indexes and demonstrates their application to geothermometry, metamorphism, structural geology, and for assessing oil and gas potential.

Conodonts, which are the microscopic hard parts of an unknown organic group, are commonly 0.1 to $1 \mathrm{~mm}$ in size (fig. 1). Several individual conodonts, in most cases, of different shape or form, belonged to one conodont apparatus or conodont-bearing organism (for example, all form elements in fig. 4, column 1.5). Conodonts have a worldwide distribution in most marine rocks of Cambrian through most of Triassic age, although their abundance varies considerably. Where deposition was rapid, conodonts may be absent or as rare as 1-2 per kilogram; where deposition was slow, there may be several thousand per kilogram. They are readily recovered from mud-drilled cuttings but are generally not re- 


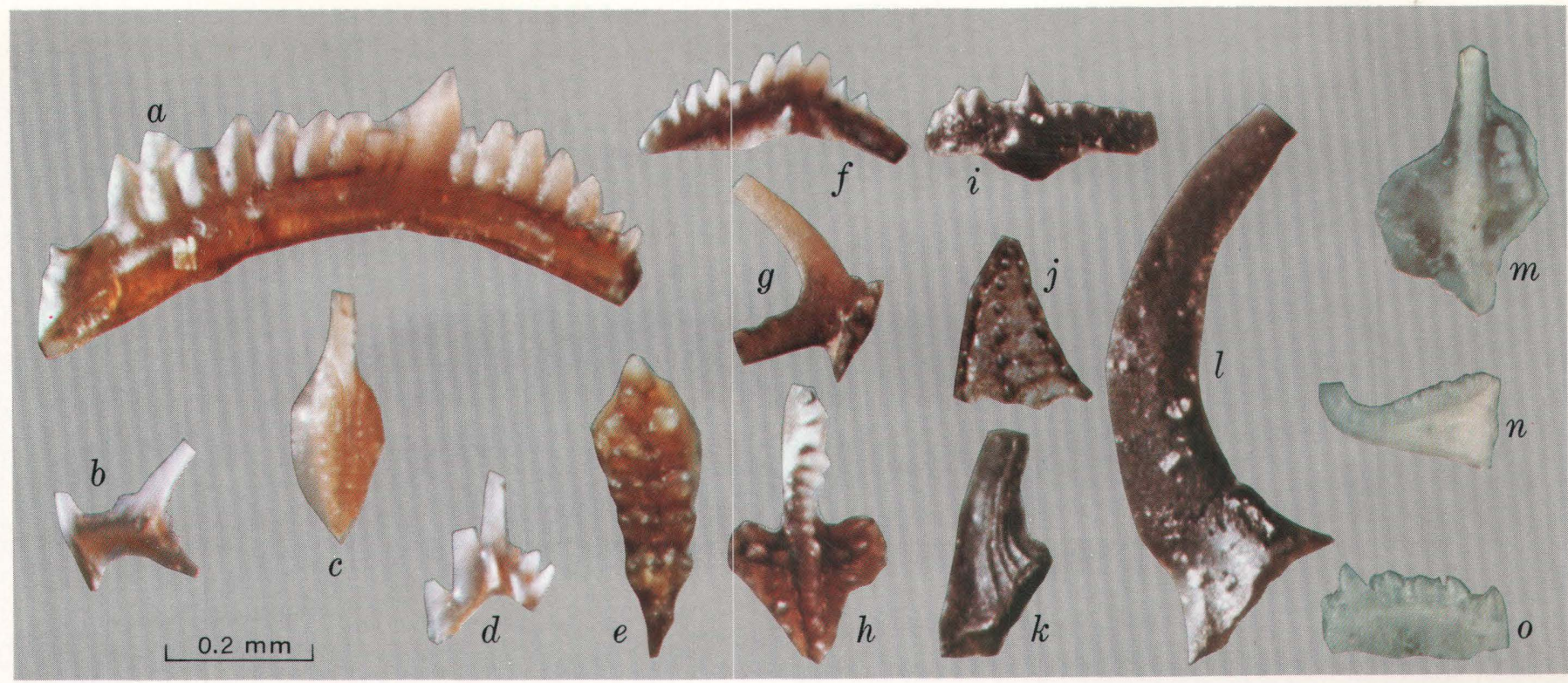

\section{CONODONTS}

1. Microfossils (generally $0.1-1 \mathrm{~mm}$ ).

2. Hard parts of an unknown organic group.

3. Several conodont elements belonged to one organism.

4. Range-Cambrian thru Triassic.

5. Worldwide distribution in most marine rocks.

6. Mineral composition-carbonate apatite.

7. Color-pale yellow, brown, black, opaque white, and crystal clear.

Figure 1.-A selection of conodont elements of diverse form, age, and color and some generalizations about conodonts. Specimens shown in figures $m-o$ were kindly given to us by H. P. Schönlaub, Geological Survey of Austria.

coverable from air-drilled cuttings which are usually finer than the lower size limit of determinable conodonts. Most important for our purposes is their mineral and chemical composition. Conodonts are essentially carbonate apatite, and approximate the mineral francolite (Pietzner and others, 1968, p. 124, show the bulk formula as $\mathrm{Ca}_{5} \mathrm{Na}_{0.14}\left(\mathrm{PO}_{4}\right)_{3.01}$ $\left.\left(\mathrm{CO}_{3}\right)_{0.16} \mathrm{~F}_{0.73}\left(\mathrm{H}_{2} \mathrm{O}\right)_{0.45}\right)$. Thus they can be easily extracted from carbonate rocks by acetic- or formicacid treatment and concentrated with heavy liquids and (or) a magnetic separator. Because of their mineral composition, they readily persist into greenschist metamorphic terranes and have even been recovered from marbles interbedded with garnetmica schists (H. P. Schönlaub, written and oral communs., 1974). Unweathered conodonts are pale yellow (fig. $1 a-d$ ), light to dark brown (fig. 1e-j), black (fig. $1 k, l$ ), opaque white (fig. $1 \mathrm{~m}$ ), and crystal clear (fig. $1 n, o$ ). If unweathered and unaltered, they are pale yellow to light amber (fig. $1 a-d$ ).

Unweathered conodonts from thin undisturbed cratonic sequences are generally pale yellow (fig. $1 a-d)$, and those from thick geosynclinal sequences that also happen to be complexly deformed are light to dark brown (fig. $1 e-j$ ), black (fig. $1 k, l$ ), opaque white (fig. $1 \mathrm{~m}$ ), and crystal clear (fig. $1 \mathrm{n}, \mathrm{o}$ ).

In 1944, Ellison reported that conodonts heated in a closed tube give off water and turn dark gray. Two decades later, Lindström (1964) correctly attributed this color alteration to a carbon-fixing process. Trace amounts of organic matter, probably amino acids, were reported from demineralized conodonts by Pietzner and others (1968). The basal part of the conodont element, which is very well laminated, contains higher concentrations of organic material than the denticles. It appears that organic matter is one of the chief contributors to conodont color.

Until now, color alteration in conodonts has not been systematically mapped nor explained, even though earlier conodont workers noted these color changes. We have evaluated these color changes by using field data-that is, by mapping conodont color throughout the Appalachian basin, and in laboratory experiments by inducing color alteration. 


\section{EXPERIMENTALLY INDUCED COLOR ALTERATION}

The literature concerning diagenesis of organic matter emphasizes heat and time as the dominant factors in carbonization and thus color alteration (see for example, Abelson, 1954; Philippi, 1965 ; Teichmüller and Teichmüller, 1968; Bostick, 1973; Hood and others, 1975).

In the experiments, we used conodonts from the Kope Formation of Late Ordovician age fom northcentral Kentucky. Conodonts from this limestone are especially well suited for this purpose because, they are abundant (about 5,000 per kilogram), well pre- served, and among the lightest colored in the Appalachian basin (fig. 2). Their pale-yellow color reflects the fact that these conodonts have had a minimal thermal history because they were never buried by more than 2,000-3,000 feet (610-910 m) of overburden, and there are no structural or intrusive complications at the collecting locality. Figure 2 shows, however, that even an unaltered assemblage of conodonts has some color variation which is related to the maturity and (or) robustness of the individual element. Larger, thicker (fig. $2 c, d$ ), or adult (fig. $2 a, d$ ) elements are darker colored than thin (fig. $2 f, g$ ), delicate (fig. $2 h$ ), or juvenile (fig.

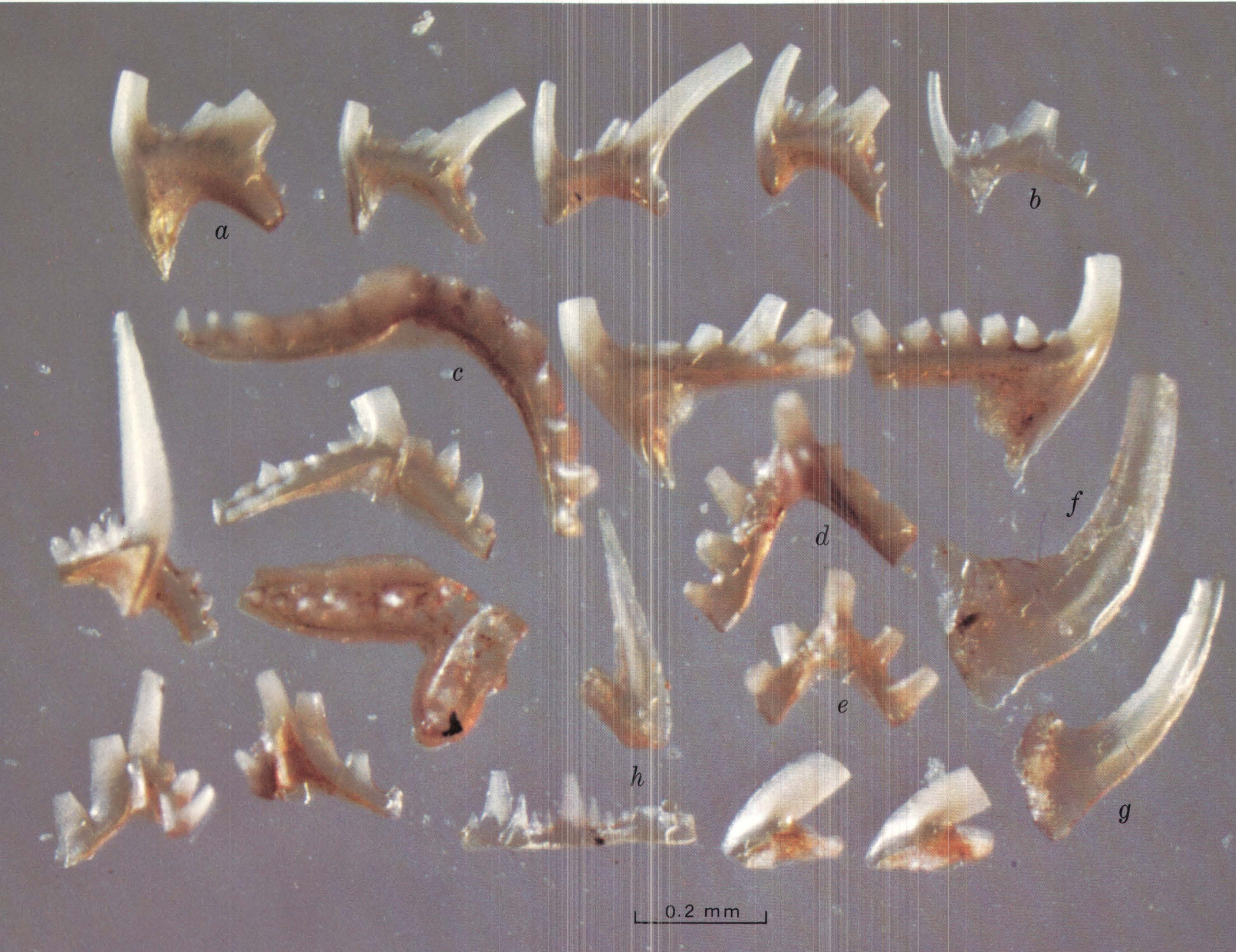

FIgURE 2.-Some Late Ordovician conodont elements from the Kope Formation of north-central Kentucky. These are among the lightest (pale yellow) conodonts in the Appalachian basin and were used to study the effects of experimental metamorphism on conodont color alteration. The collecting locality (60G81) and conodonts are described in Bergström and Sweet (1966). Lettered conodonts are discussed in the text. 
$2 b, e$ ) elements because the larger conodonts have more lamellae and thus more interlamellar spaces containing organic matter.

\section{OPEN-AIR HEATING RUNS}

The pale-yellow conodonts were heated in an electric furnace, in covered porcelain crucibles, in air, at $50^{\circ} \mathrm{C}$-increments from $300^{\circ}-600^{\circ} \mathrm{C}$ and from 10 to 50 days. Specimens were pulled at regular intervals so that there is a permanent record of color change. Figure 3 is an Ahrrenius plot of the data. The experiments showed that:

1. The sequence of color change from pale yellow to black found in field collections is the same as that produced by heating alone.

2. Color alteration is progressive, cumulative, and irreversible.
3. Color alteration is time and temperature dependent. At $300^{\circ} \mathrm{C}$, color alteration begins after 350 hours of heating; at $400^{\circ} \mathrm{C}$, after 5 hours of heating; at $500^{\circ} \mathrm{C}$, after only half an hour of heating.

4. A comparison of the experimental data with field collections indicated that five color intervals could be readily discriminated. These are numbered and termed color alteration indexes (CAI).

\section{DETERMINATION OF COLOR ALTERATION INDEX (CAI)}

Figure 4 shows experimentally altered conodonts that represent all CAI values. It is mainly the basal pale yellow to amber part of the unaltered conodont element that changes color. The white matter, which

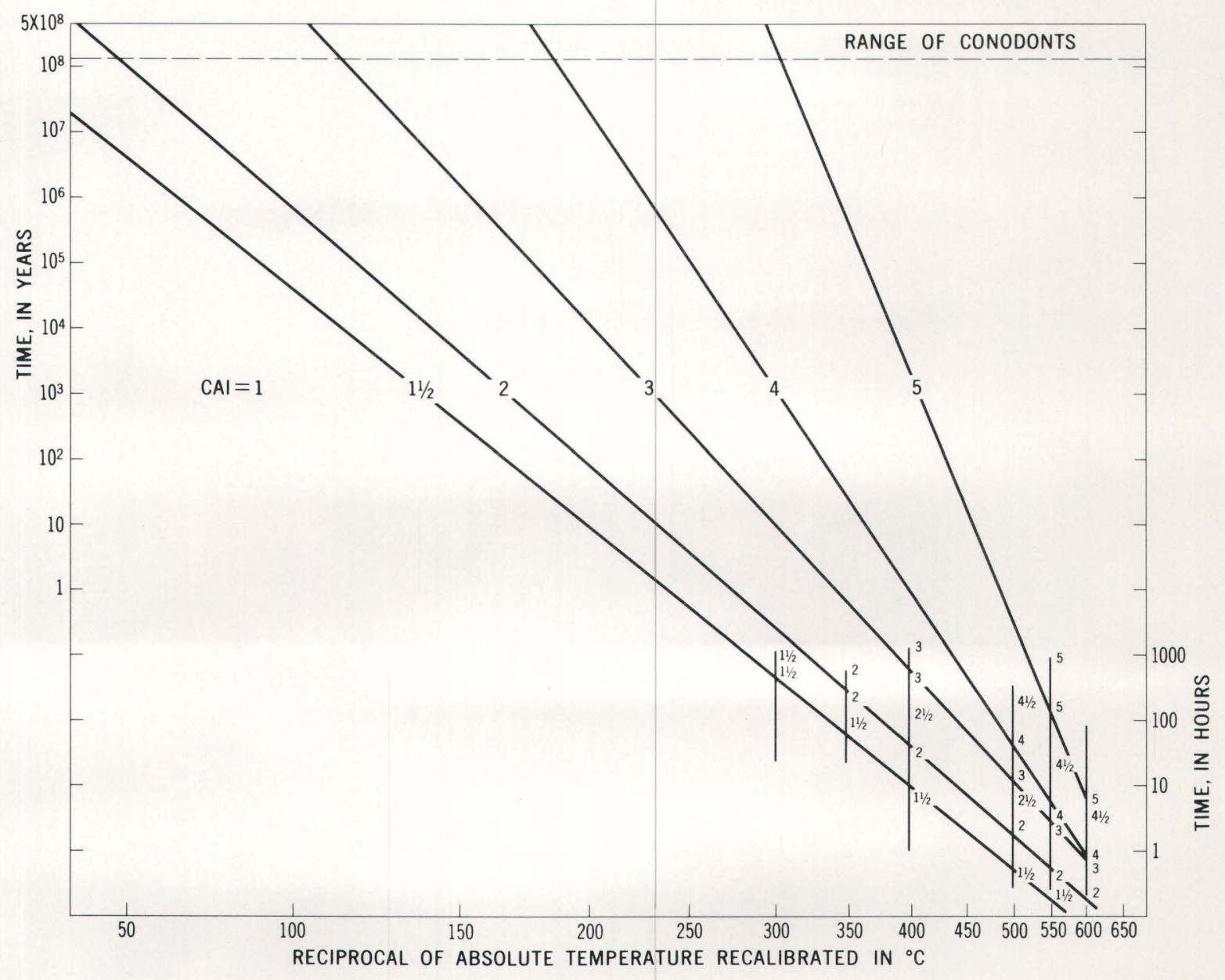

Figure 3.-Ahrrenius plot of the heat-induced, open-air, conodont color alteration data. Vertical bars represent duration of heating runs at constant temperature. For the $300^{\circ}-400^{\circ} \mathrm{C}$ runs, conodonts were pulled every 24 hours; for higher temperature runs, conodonts were pulled every half hour or hour for the first 24 hours and at 24-hour intervals thereafter. Diagonal lines bound color alteration index (CAI) fields. 


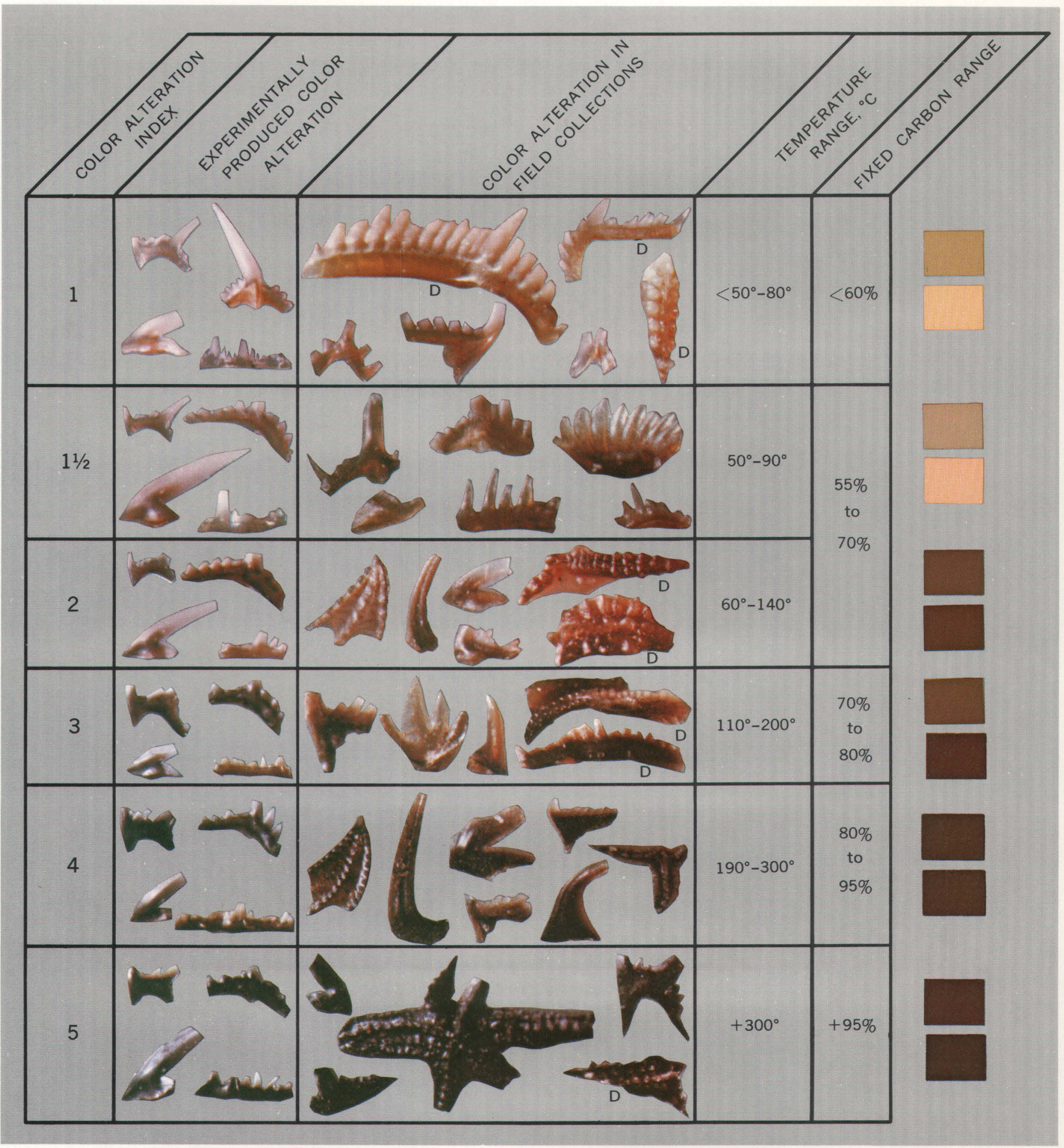

FIgURe 5.-(For explanation see facing page.)

determine the alteration index from the lightest colored elements or parts of elements. If only robust elements are present, CAI is determined on the thin edge of an element. The same procedure is used in determining palynomorph translucency, where wall thickness, ornamentation, or reworking produce similar variations in color in a palynomorph assemblage (Staplin, 1969).

Naturally occurring conodont collections that have a CAI of 4.5 or higher, show changes in surface texture as well as color. At these high indexes, conodont surfaces change from smooth and vitreous 


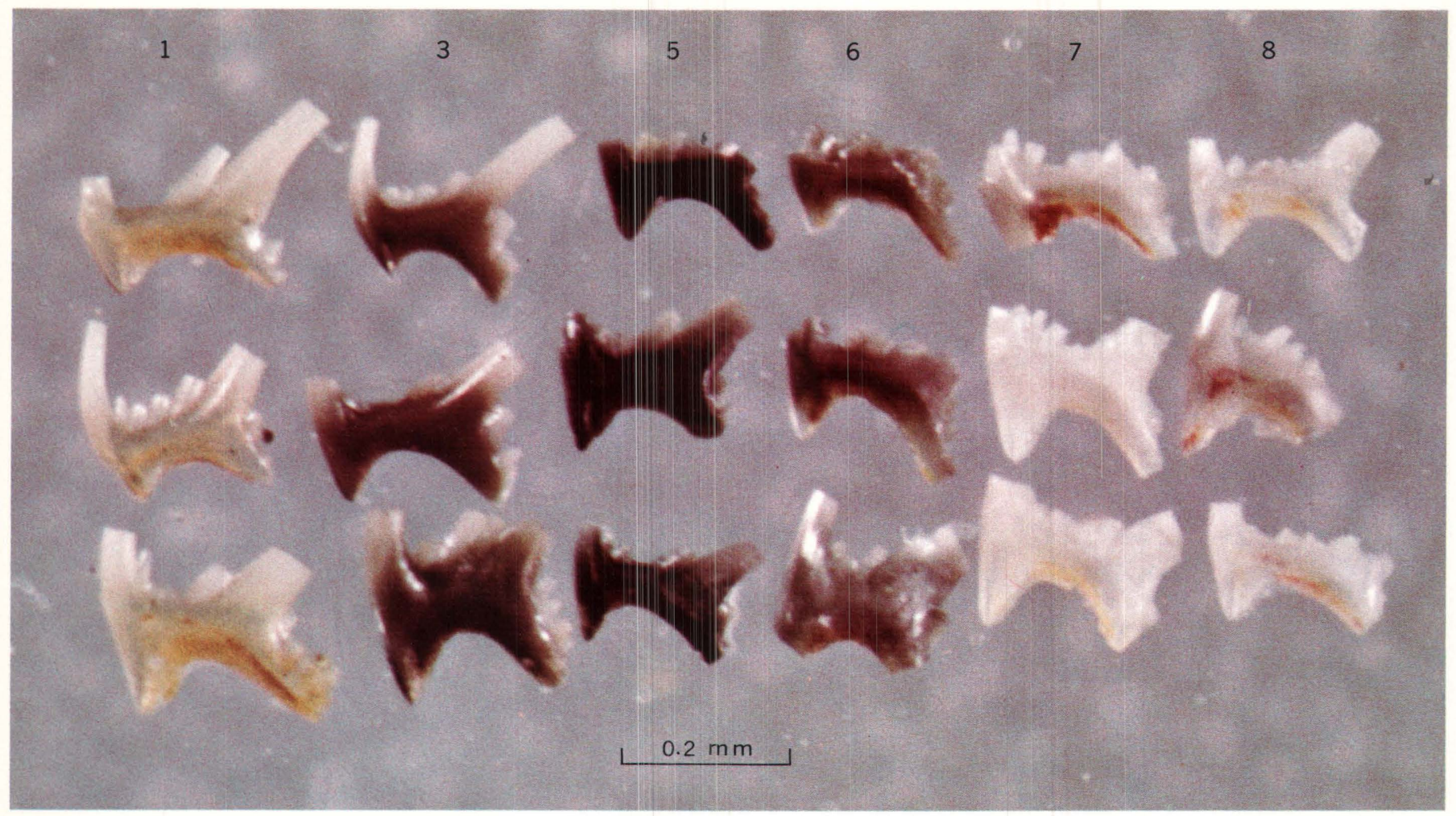

FIGURE 6.-Naturally occurring pale-yellow (CAI 1) and heat-induced dark-brown (CAI 3), black (CAI 5), gray (CAI 6), opaque white (CAI 7), and nearly crystal-clear (CAI 8) phragmodiform elements. CAI 8 was produced by heating paleyellow conodonts wrapped in platinum foil in an open-air electric furnace at $950^{\circ} \mathrm{C}$ for 4 hours.

FIGURE 5.-Chart showing experimentally produced and naturally occurring colors in conodonts and the geologic-temperature and fixed-carbon range for each CAI.

The shape and size of conodonts affects their color. Even though the experimental conodonts shown are all form elements of Phragmodus undatus Branson and Mehl, there is still some range in color within each index because of the robustness or delicateness of the various specimens. If, however, the same form element is compared for all indexes (for example, the thin bar fragment of the phragmodiform element in the lower right of each box), the index sequence is obvious. Robust elements should not be compared with delicate elements. Note too that once CAI 5 is reached, all morphotypes are black. In center column, specimens labeled D are Devonian, all others are Ordovician. Specimens shown in the column for CAI 1.5 are mostly robust hyaline forms (elements that virtually lack white matter) and therefore appear darker than many conodonts of slightly higher index. The temperature ranges are from the Ahrrenius plot of the experimental data (fig. 3). These ranges cover durations of 1 million to 500 million years. The higher temperature value is therefore extreme and in most geologic situations the temperature determination would be near the lower end of the temperature range (the method for temperature determination is shown in fig. 9). The fixed carbon values are from reflectance determinations on vitrinite obtained from the same field samples as indexed conodonts. The color range for each CAI is also shown by Munsell soil color chips, color values are given in table 1 . to pitted and grainy. The high temperatures that produce these high indexes undoubtedly also promote corrosion of the conodont surface.

We are now in the process of extending the color chart (fig. 5) into higher temperature ranges. With continued heating, black conodonts become gray, then opaque white, and in the last stage before decomposition, crystal clear (fig. 6). We believe that the fixed carbon of the black conodont is driven out of the conodont element (volatilized) at these high temperatures, thus clearing the conodont element. The change from opaque white to crystal clear conodonts may result from the release of water of crystallization (see "Introduction," this report, for bulk chemical formula) as well as from recrystallization.

Recently (1974), conodonts have been recovered from increasingly higher grade regional metamorphic facies in the Austrian Alps by H. P. Schönlaub, Geological Survey of Austria (written commun., 1974). We gratefully acknowledge his adventuresomeness in processing these high-grade carbonates for conodonts and for allowing us to use his specimens in our study (fig. 7). Thermal alteration and metamorphic grade increase from left to 


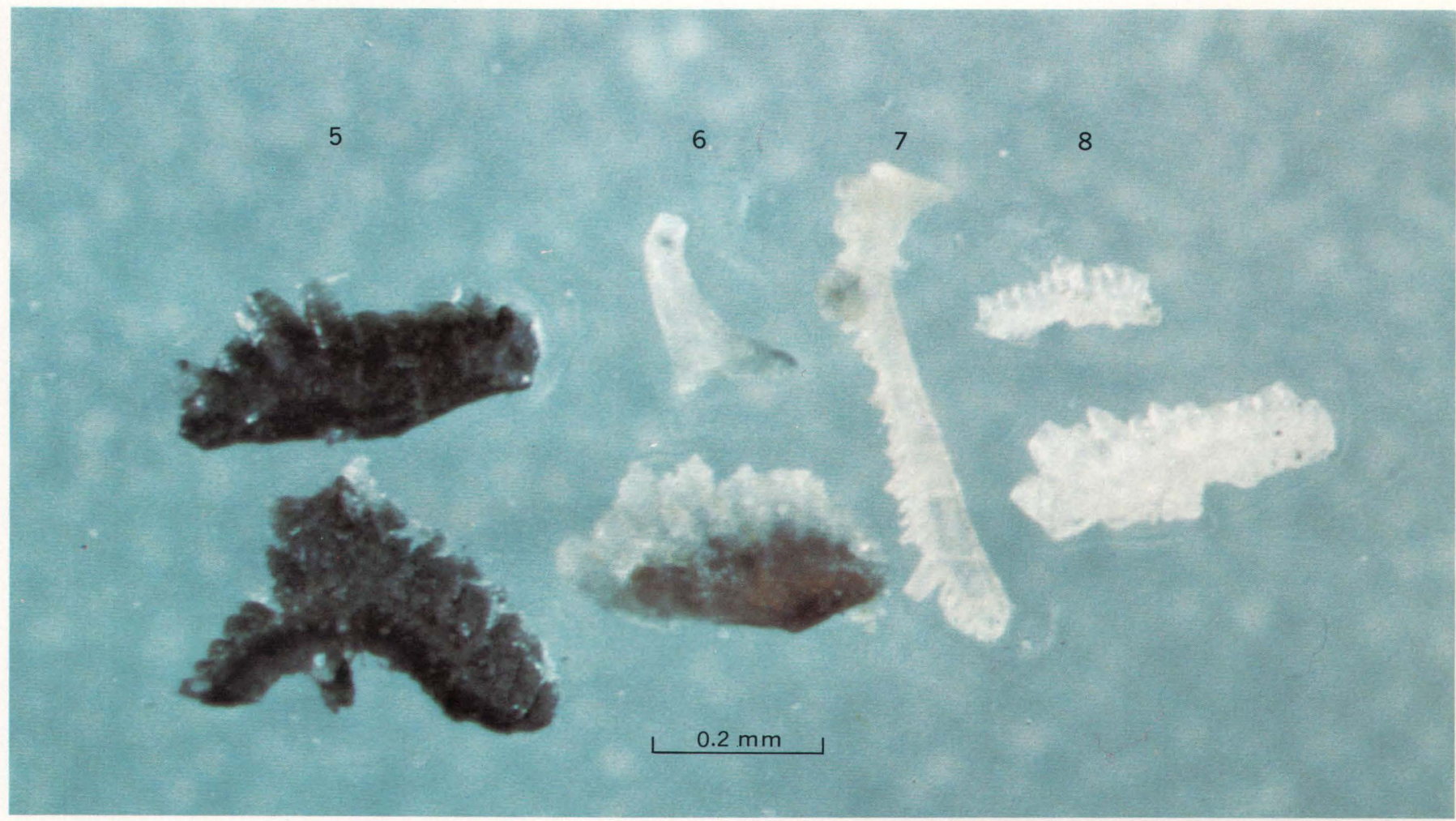

FIGURE 7.-Conodont elements from carbonate rocks within chlorite- (CAI 5) through garnet- (CAI 8) grade metamorphic facies in the Austrian Alps. CAI 5 and 6 specimens are from Lower Silurian carbonate rocks interbedded with slates at Radmer, Austria, and are from collections about $100 \mathrm{~m}$ apart; CAI 7, from lower Middle Devonian carbonate rocks, Styria, Austria; CAI 8, from Upper Silurian marbles interbedded with garnet-mica schists, serpentinites, and amphibolites, Salzburg, Austria.

right (fig. 7), from black (chlorite grade), to gray, to opaque white, and finally crystal-clear conodonts from marbles interbedded with garnet-mica schists, serpentinites, and amphibolites. We produced nearly crystal-clear conodonts in the laboratory by heating at $950^{\circ} \mathrm{C}$ for 4 hours (fig. 6, column indexed 8). Schönlaub has noted (written commun., 1974) that the two collections from Radmer, Austria, although only $100 \mathrm{~m}$ apart, have conodonts of very different color; black conodonts (CAI 5) were recovered from black platy carbonate rock interbedded with black slates (fig. 7) ; gray to opaque white (CAI 6) conodonts were recovered from light-gray carbonate rock (fig. 7). Schönlaub suggests that the different host and (or) adjacent rock at this locality may be affecting conodont color alteration. Schönlaub also states (written commun., 1974) that other samples only a few metres apart from the Styrian "Erzberg," contain black, gray, opaque white, and transition (column 6 lower specimen) conodonts. The black to gray to opaque white transition may be very short lived. CAI 6 may overlap the upper and lower temperature ranges of CAI 5 and CAI 7 , respectively.
In addition, we sampled several localities in the western United States where carbonate rocks containing pale-yellow conodonts are intruded by small dikes or sills or are in contact with lava flows. At each locality the thermal effect of the intrusive or extrusive body was recorded by conodont color alteration; conodonts changed from white to black to brown to pale yellow with increasing distance from the igneous body.

The alteration index of conodont elements can be determined by any of the following procedures:

1. Starting with pale-yellow conodonts, a set of standards can be cooked in open air in an electric furnace using the following recipe:

$\mathrm{CAI}=1.5$, heat for half an hour at $500^{\circ} \mathrm{C}$. $\mathrm{CAI}=2$, heat for 3 hours at $500^{\circ} \mathrm{C}$.

$\mathrm{CAI}=3$, heat for 14 hours at $500^{\circ} \mathrm{C}$.

$\mathrm{CAI}=4$, heat for 8 hours at $550^{\circ} \mathrm{C}$.

$\mathrm{CAI}=5$, heat for 48 hours at $600^{\circ} \mathrm{C}$.

Clusters of each laboratory-produced index are then placed on a clear glass slide overlying a ground glass plate. The unknowns can then be placed amid or adjacent to each cluster; a 
best match is determined under a binocular microscope using unfiltered reflected light.

2. A set of standards can be assembled from field collections. Then follow the procedure outlined in 1. It is helpful to have several sets of standards representing conodonts of different ages and morphotypes.

3. The Munsell soil color chips given for each index in table 1 can be mounted in sequence on gray mounting board. The conodonts are placed on the gray board adjacent to the chip and matched under a binocular microscope.

4. The conodonts shown on the color chart (fig. 5) can be cut out and placed in sequence on gray mounting board. CAI value can then be determined using the same procedure as in 3 .

If conodonts cannot be freed from their matrix (conodonts exposed on bedding plane of clastic rock or chert), the CAI value may be crudely determined by placing conodont standards on the host rock adjacent to the embedded conodont and selecting a best match.

DOES PRESSURE AFFECT COLOR ALTERATION?

The long-term experiments showed that conodonts heated at $550^{\circ} \mathrm{C}$ for 3 hours in open air have a CAI value of 3 (figs. 3, 8) .Using argon and then methane as pressure media, the Kope Formation conodonts (fig. 2) were sealed in platinum capsules and heated at $550^{\circ} \mathrm{C}$ for 3 hours at 1 kilobar (kbar) in bombsthe CAI value was the same as in open air (fig. 8). Confined pressure and anoxic conditions neither retarded nor accelerated carbonization. Huck and Patteisky (1964) showed similar results involving experimental metamorphism of coal. They reported an increase in rank from 67 to 82 percent fixed carbon for coal heated in a vacuum at $350^{\circ} \mathrm{C}$ and that the same coal heated at the same temperature, but at 8,000 atmospheres still maintained the 67 to 82 percent change in fixed carbon. Bostick (1970) also reported no change in vitrinite reflectance of phytoclasts from runs in which temperature was kept constant and pressure was varied from 260 to 1,650 bars. McIntyre (1972), however, in his study on the effect of experimental metamorphism on pollen in a lignite, stated that his experiments showed that pressure retards carbonization. Unfortunately his data (1972, table 1) do not appear to support his conclusion.

The Kope Formation conodonts were next heated in open air in an electric furnace having a continuous

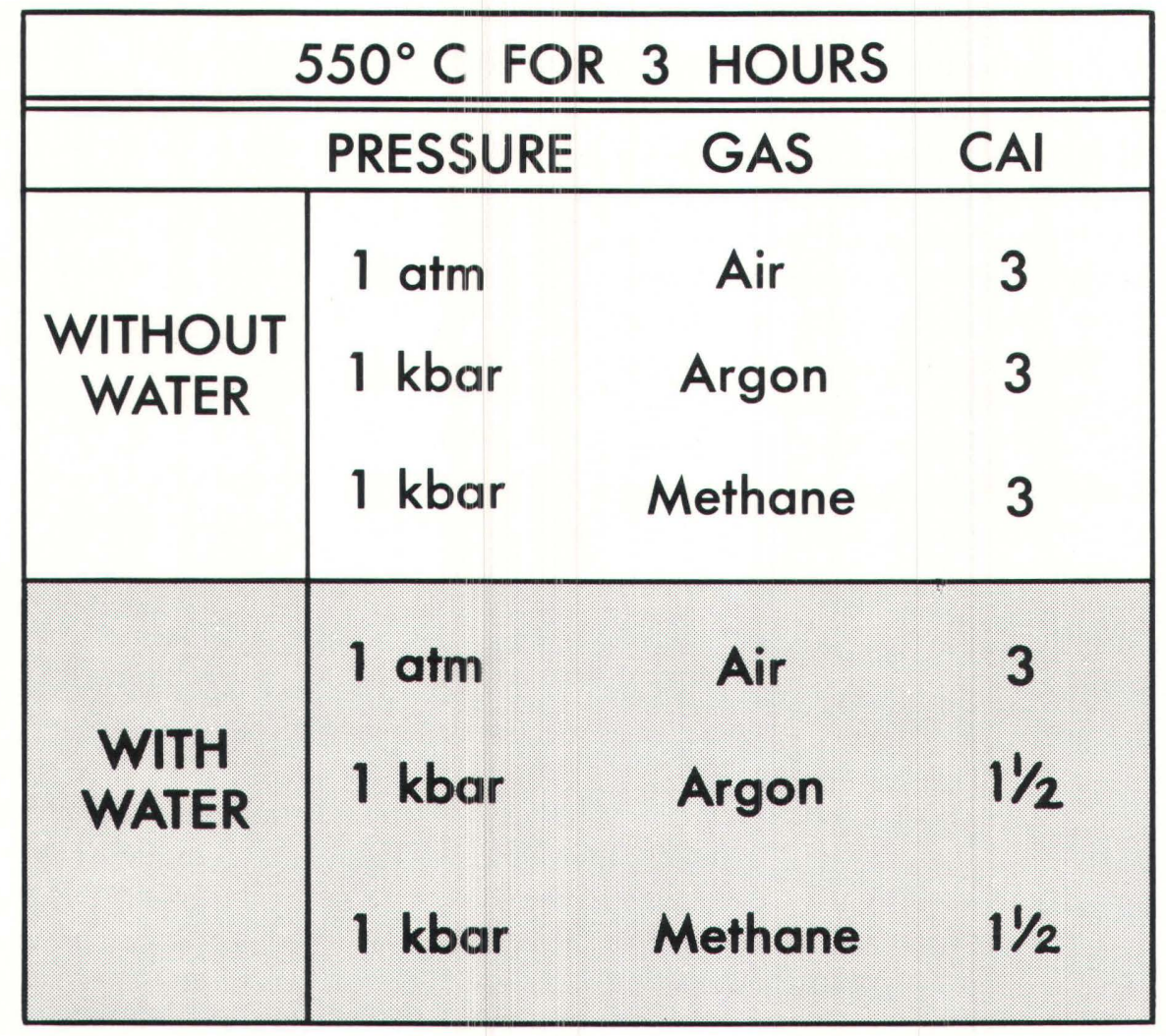

FIGURE 8.-Chart showing CAI for conodonts subjected to different pressures and chemical environments while under the same conditions of time and temperature. 
water-vapor feed. All conodont pulls had the same CAI values as conodonts heated under the same conditions of time and temperature, but without water.

Using argon and then methane as pressure media, conodonts were sealed in platinum capsules containing distilled water. The conodonts recovered after 3 hours of $550^{\circ} \mathrm{C}$ heating at $1 \mathrm{kbar}$ had a CAI of 1.5 (fig. 8). Thus, in a sealed system, water in combination with confined pressure and heat considerably retards carbonization. Consequently, the open-air experimental temperature data cannot be applied to wet sealed systems at relatively high pressure, simply because, the temperature determinations would be too low. The assessment of the organic maturity, however, would still be accurate. This helps explain oil production at anomalously high temperatures from overpressured rocks.

\section{EVALUATION OF EXPERIMENTAL DATA USING FIELD COLLECTIONS OF CONODONTS}

\section{CAI AS A GEOTHERMOMETER}

Conodonts from Monterey, Va., in the Valley and Ridge province, were compared with our standards and were determined to have a CAI value between 4 and 4.5. The conodonts are of Middle Ordovician age; thus the maximum possible time for burial and heating could be as long as 470 m.y. One can, however, impose a few time limits from a knowledge of Appalachian geology. The Middle Triassic is the latest possible time for beginning of unloading by erosion in this part of the Appalachian basin. Therefore, $270 \mathrm{~m} . \mathrm{y}$. is the maximum possible time for burial and heating, thus providing the lowest possible temperature for conodonts of CAI 4-4.5 (fig. 9, heavy solid lines). Projecting the 4-4.5 field segment of the 270 m.y.-line to the $x$ axis yields a temperature range of $185^{\circ}-220^{\circ} \mathrm{C}$ for these conodonts. If, however, unloading began in the Late Pennsylvanian, which is the earliest possible time for unloading in this part of the basin, the maximum time for burial and heating is 210 m.y. (fig. 9, dashed lines), thus a maximum temperature range of $190^{\circ}-$ $230^{\circ} \mathrm{C}$. This temperature range is very close to the first determination, showing that time becomes less important beyond durations of about 50 million years.

Are these calculated temperatures compatible with field geologic data? In the vicinity of Monterey, at least 14,300 feet $(4,770 \mathrm{~m})$ of rock is known to overlie the Middle Ordovician (fig. 9). Assuming an average geothermal gradient of $1^{\circ} \mathrm{C}$ per 100 feet, known overburden alone can account for a temperature of $160^{\circ} \mathrm{C}$. In the calculation we have not taken into account the thickening of section by folding and faulting, nor have we tried to completely restore missing section. In spite of this, the temperatures determined from the Ahrrenius plot are compatible with isopach data. Moreover, Paleozoic rocks in the Monterey area are cut by Cenozoic intrusions. The additional $30^{\circ}-70^{\circ} \mathrm{C}$ can easily be accounted for by a higher than average Cenozoic geothermal gradient.

\section{DO TECTONICS INFLUENGE COLOR ALTERATION OR CARBONIZATION?}

Several regional coal-rank studies have shown that depth of burial and not amount of deformation is the main influence on carbonization or coalification. In many terranes containing coal-bearing sequences, the highest rank of coalification is usually reached during the period of greatest depth of burial, which may be pre-orogenic. Tectonism appears to influence coalification only where it has increased depth of burial. Patteisky and others (1962) reported that in the Ruhr basin of western Germany, the lowest rank of one particular coal seam occurs where folding and thrusting are most prominent, but where burial of the seam was minimal. Hacquebard and Donaldson (1974), similarly reported the preservation of pre-orogenic coalification patterns in Jurassic and Cretaceous coal-bearing strata in the Rocky Mountains and inner foothills belt of Canada, because rank increases uniformly with depth of burial, irrespective of geologic age or amount of deformation. Damberger, in his 1974 study of coalification patterns of Pennsylvanian coal basins in eastern United States reported that coal rank in most of the basins was determined during the main phase of coalification, that is during the Pennsylvanian and Permian, and thus reflects former greatest depths of burial.

Our laboratory experiments show that confined pressure in conjunction with time and temperature neither retards nor accelerates carbonization.

The effects of overburden as well as tectonism on conodont color can be readily assessed in the northeastern part of the Appalachian basin. Figure 10 shows a selection of localities for Early and early Middle Devonian conodonts in New York and Pennsylvania. The value at each locality is the total thickness of known overburden with no attempt to account for missing section. In western New York, overburden is relatively thin $(4,000 \mathrm{ft} ; 1,220 \mathrm{~m})$ and conodonts are only slightly altered (CAI 1.5-2) Devonian rocks are virtually flat lying across New York. Only the easternmost part of the outcrop belt 


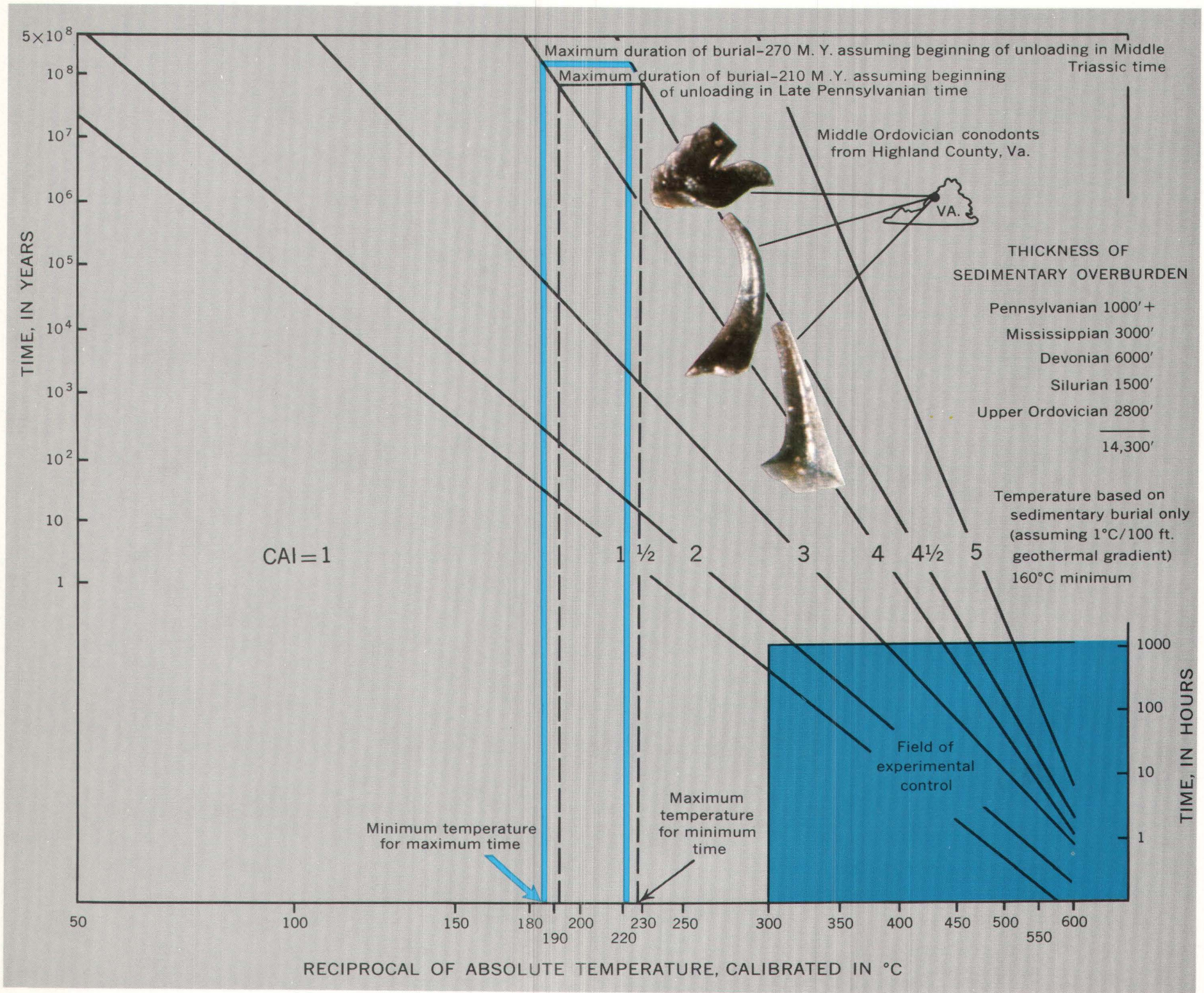

Figure 9.-Ahrrenius plot of data from conodont open-air heating runs (same plot as in fig. 3) showing best color fit for Middle Ordovician conodonts from the Valley and Ridge province near Monterey, Va. The CAI of these conodonts was determined by comparing them with index standards. Use of this plot for determination of minimum and maximum temperature ranges of conodont samples is explained in the text.

is within the folded and faulted Valley and Ridge province, which begins just west of Albany (fig. 10, red line). Conodont color, however, gradually darkens across New York and no abrupt color change occurs east or west of the tectonic front. (See fig. 16.) The color alteration in New York conforms chiefly to the eastward-thickening wedge of Upper Devonian clastic rocks. (See Oliver and others, 1971, sheet 6.) Conodonts in south-central Pennsylvania in the western part of the folded and faulted Valley and Ridge province are the same color as conodonts in flat-lying rocks, but with comparable overburden, in east-central New York. The darkest conodonts are in outliers east of the main outcrop belts and adjacent to the anthracite fields in eastern Pennsylvania, where Mississippian and Pennsylvanian rocks are thickest. Thus, it seems likely that tectonics do not affect color alteration in conodonts, but that depth of burial and the attendant increase in temperature is the dominant factor in observed conodont color alteration or carbonization. 


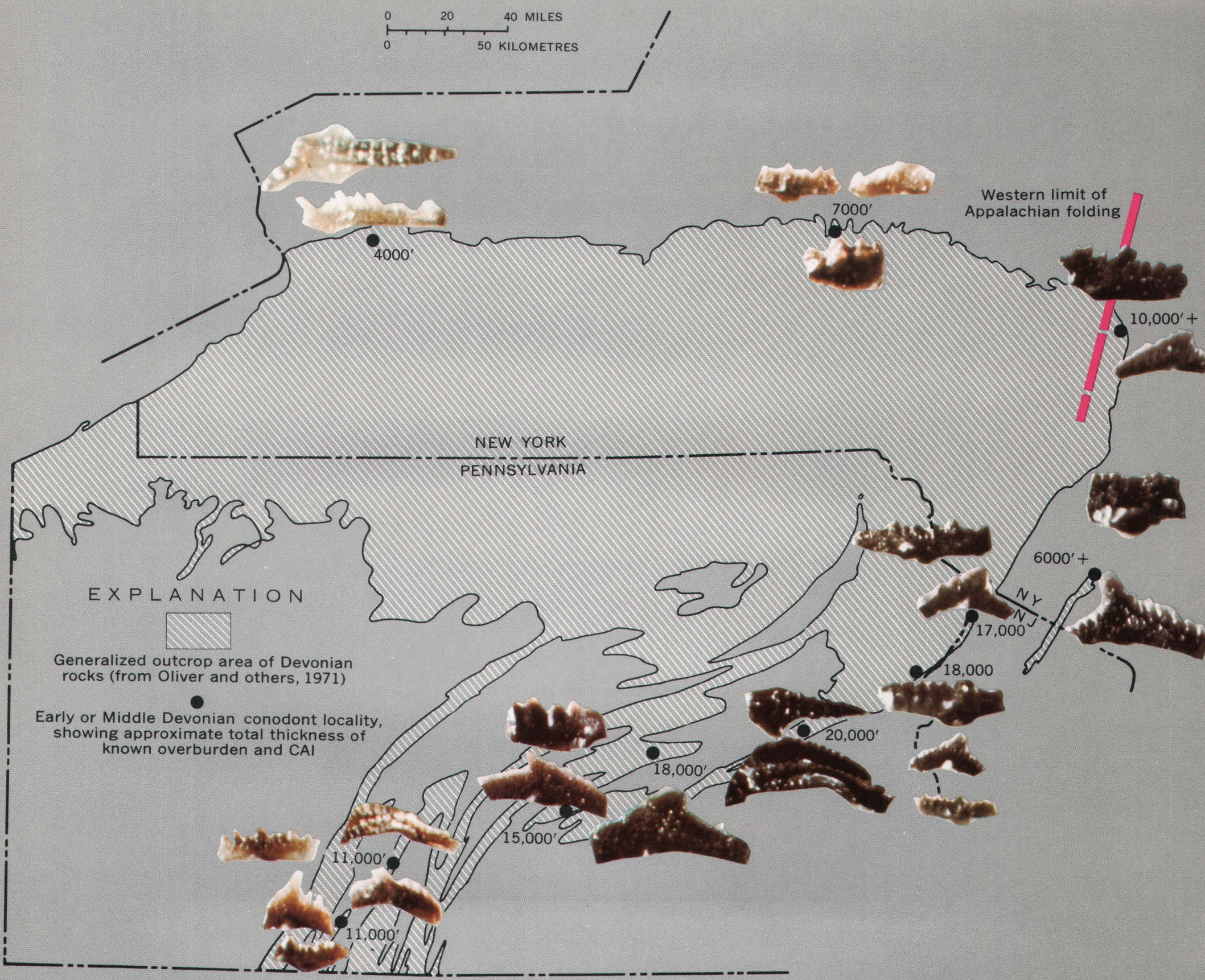

FIGURE 10.-Map showing selected localities for Early and early Middle Devonian conodonts in the northeastern part of the Appalachian basin. Conodonts, CAI, and known overburden are shown for each locality. Note the correlation of conodont color (CAI) with thickness of overburden regardless of tectonic setting (compare south-central Pennsylvania with central New York). The thicker the overburden, the darker the conodont!

CORRELATION OF CONODONT CAI WITH OTHER ORGANIC MATURITY INDEXES

All our field collections of conodonts are from the Appalachian basin. At the beginning of our study, we had hoped to tie conodont color alteration to percent fixed carbon via the isocarb (or isorank) maps for Carboniferous coals that are available for most of the Appalachian basin (Damberger, 1974, figs. 6, 7, and map references cited on p. 71). These maps are based on bulk chemical analysis of coals 
or on vitrinite reflectance. Unfortunately, conodonts were absent from the few marine carbonate rocks interbedded with the higher rank coals of the eastern half of the northern Appalachian basin. Thus, it was necessary to correlate conodont CAI with percent fixed carbon using chemical analysis of the conodont host rock or another organic maturity index.

Amoco Production Company kindly analyzed 66 of our conodont-bearing limestones from throughout Appalachian basin for weight percent fixed carbon in kerogen. Surprisingly, there was not enough kerogen in any of the 66500 -gram samples to make this determination. The clean marine carbonate rocks in which conodonts are abundant are disappointingly low in kerogen. Fortunately the conodontbearing samples also contained palynomorphs and vitrinite which could be tied to previous chemically determined fixed-carbon standards. Palynomorph translucency (Gutjahr, 1966; Staplin, 1969; Correia, 1971) and vitrinite reflectance measurements (Bostick, 1970 ; Castaño and Sparks, 1974; Hacquebard and Donaldson, 1970; Patteisky and others, 1962; Teichmüller and Teichmüller, 1968) were made using the same rock samples from which conodont CAI had been determined. Figure 11 shows the correlation of these three indexes. The columns under conodonts give CAI and temperature ranges derived from the Ahrrenius plot of the experimental data. The columns for palynomorphs give the translucency carbonization indexes used by Amoco Production Company. The values are visual estimates made using transmitted-light comparison of an unknown to a specific palynomorph translucency standard. Amoco has equated their translucency indexes to weight percent fixed carbon in kerogen and these values are also shown here. The palynomorph correlation is based on 66 limestone samples of Ordovician through Mississippian age from the Appalachian basin. Seven percent of the samples (not in- cluded in the 66) originally submitted for processing had no palynomorphs; these were mainly samples of deep-water limestone.

Conodont color alteration does not begin until a late stage of palynomorph diagenesis (fig. 11). Thus, CAI 1 equals translucency indexes 1 through 5 . Palynomorphs, therefore, and not conodonts, are excellent indicators of low-temperature organic metamorphism. They have been successfully used in the petroleum industry as low-level organic maturity indexes, especially in the critical realm of threshold hydrocarbon generation (Gutjahr, 1966; Staplin, 1969; Correia, 1971; Staplin and others, in press). Conversely, palynomorphs are cruder indexes of late-stage organic metamorphism than conodonts (fig. 11). Moreover, vitrinite reflectance measurements on many of the same samples used to correlate conodont CAI and palynomorph translucency, corroborate the greater accuracy of conodont CAI at these high levels of organic metamorphism.

Palynomorph and conodont indexes dovetail nicely; palynomorphs provide an accurate assessment of early-stage organic metamorphism and are best preserved and most abundant in clastic rocks; conodonts provide a better assessment of late-stage organic metamorphism and are most easily obtained from carbonate rocks.

The vitrinite correlation (fig. 11) is based on 20 limestone samples of Devonian and Mississippian age from the Appalachian basin. Many more samples were processed for vitrinite; unfortunately, 42 percent of all samples processed had none. Vitrinite is least abundant in the relatively clean marine carbonates in which conodonts are most abundant. Because so many of the conodont samples lacked vitrinite, we tried to obtain reflectance readings on the very fine dispersed organic matter within the conodont element itself. The mineralogy of the conodont interfered with and made reflectance readings on

\begin{tabular}{cc}
\multicolumn{2}{c}{ CONODONTS } \\
\hline \multicolumn{2}{c}{ TEMEPERATURE } \\
CAI & ${ }^{\circ} \mathrm{C}$ \\
1 & $<50-80$ \\
$11 / 2$ & $50-90$ \\
2 & $60-140$ \\
3 & $110-200$ \\
4 & $190-300$ \\
5 & $300-400$
\end{tabular}

\begin{tabular}{|c|c|}
\hline \multicolumn{2}{|c|}{ PALYNOMORPHS } \\
\hline $\begin{array}{l}\text { TRANSLUCENCY } \\
\text { INDEX (AMOCO) }\end{array}$ & $\begin{array}{l}\text { WEIGHT PERCENT } \\
\text { CARBON IN } \\
\text { KEROGEN }\end{array}$ \\
\hline $\begin{array}{c}1-5 \\
5-\text { up. } 5 \\
5-6 \\
\text { up. } 5-6 \\
6 \\
\text { up. } 6-7\end{array}$ & $\begin{array}{c}<82 \\
81-84 \\
81-87 \\
83-89 \\
84-90 \\
+90\end{array}$ \\
\hline
\end{tabular}

Figure 11.-Chart showing correlation of three organic metamorphism indexes; all are optical techniques. Palynomorph translucency and vitrinite reflectance determinations were made on the same rock samples from which conodont CAI had been determined. The temperature ranges for conodonts are from the Ahrrenius plot of the experimental data and represent heating durations of 500 million to 1 million years (lower temperature is $500 \mathrm{~m} . \mathrm{y}$.-value). The upper temperature limit for CAI 5 is from experiments now in progress. The translucency indexes are mean range values and are visual comparison estimates and not photometric determinations. 
the organic matter impossible. Vitrinite reflectance determinations were also used to check areas where conodont CAI appeared to be geologically anomalous. In all cases, the vitrinite data corroborated the CAI values (see fig. 16, area of high CAI and correspondingly high reflectance in Maryland and West Virginia). According to most investigators, (for example, Hacquebard and Donaldson, 1970; Bostick, 1974), vitrinite reflectance measurements are best at high levels of organic metamorphism-above 62 percent fixed carbon. Vitrinite is generally confined to Devonian through Quaternary deposits and is most abundant in fine-grained clastic rocks; conodonts, on the other hand, are found in marine, chiefly carbonate and to a lesser extent, clastic rocks of Cambrian through Triassic age.

The three optical indexes of organic maturity can be compared for age and thermal range, and ease and expense of laboratory preparation and index determination (fig. 12). The age and thermal ranges of the three indexes combine well to cover most geologic conditions. Conodonts overlap and extend below the age range of vitrinite, providing a good index of maturity for Ordovician and Silurian rocks, and to a lesser extent, of Cambrian rocks where conodonts are rare.

Palynomorphs are longer ranging than either conodonts or vitrinite (fig. 12). Palynomorphs can be used to assess organic metamorphism in terranes where maximum temperatures were never higher than $50^{\circ} \mathrm{C}$ or where fixed carbon values are less than 60 percent. Many spores and pollen do not survive in terranes where fixed carbon is greater than 70 percent (Wilson, 1961). Vitrinite can be read to 100 percent fixed carbon equivalence or even to graphite-grade metamorphic facies (Schapiro and Gray, 1966). According to Bostick (1974), vitrinite reflectance measurements are most applicable above $80^{\circ} \mathrm{C}$. Conodonts extend into garnet-grade metamorphic facies where rocks have been regionally subjected to temperatures as high as $500^{\circ} \mathrm{C}$. Conodont CAI cannot discriminate temperature intervals below $50^{\circ} \mathrm{C}$.
Who can make conodont CAI determinations? In contrast to palynomorph and vitrinite indexing which require a trained operator with technical skills (determinations are generally made by a palynologist or coal petrologist), conodont indexing can be accomplished by anyone who isn't color blind. The cost of conodont preparation and indexing is relatively small. Preparation of carbonate samples requires acetic- or formic-acid demineralization followed by heavy-liquid separation using bromoform or tetrabromethane, and then color determination with a standard binocular microscope. Palynomorph translucency indexing requires a more chemically complicated concentration procedure, followed by either a rapid and inexpensive visual comparison using translucency standards for index determination, or by a more expensive photometric determination. (See Gutjahr, 1966, for a description of laboratory processing and photometric determination.) Commercial laboratories price organic-maturity assessment using palynomorph translucency techniques at $\$ 30-\$ 50$ per sample (1975).

Vitrinite analysis involves concentration techniques similar to those for palynomorphs but requires a more careful and complicated mounting procedure, as well as more sophisticated and expensive optical hardware. Vitrinite reflectance determinations are made by some major oil companies and a few state and federal coal laboratories. Commercial laboratories charge $\$ 40-\$ 180$ per sample for reflectance determination (1975).

\section{EFFECTS OF HOST ROCK ON ORGANIC METAMORPHISM}

We had initially intended to correlate conodont CAI in Pennsylvanian carbonate rocks to existing fixed-carbon determinations (chemical and optical) in nearby or interbedded coals. This correlation was not possible. We did, however, plot the vitrinite fixed-carbon values obtained from our Devonian and Mississippian carbonate rocks on Pennsylvanian coal ioscarb maps (Ashley, 1928; Damberger, 1974; Eby, 1923; Meyer and Edgerton, 1968; Postley,

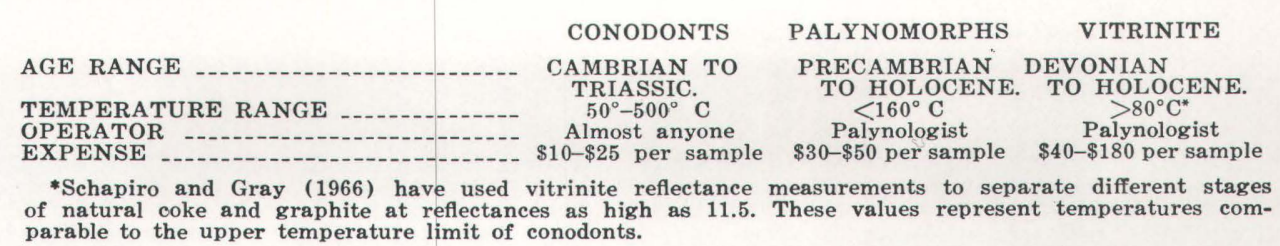

FIgURE 12.-Chart comparing age and thermal range and relative cost of three organic maturity indexes; all are optical techniques. 
1935). Vitrinite fixed-carbon values from the carbonate rocks averaged 7 percent fixed-carbon points lower than fixed-carbon values of Pennsylvanian coals in the same area. This was surprising, especially as the limestones were $1,000(305 \mathrm{~m})$ to 7,000 $(2,135 \mathrm{~m})$ feet stratigraphically below the Pennsylvanian coals. The literature on vitrinite reflectance indicates some controversy concerning the influence of host-rock lithology on reflectance. Some workers have found that vitrinite scattered in country rocks often has the same or only slightly different reflectance values than vitrinite in adjacent coal beds (Ammosov, 1970). Castaño and Sparks (1974) found virtually no difference in vitrinite reflectance of coal-shale pairs, provided that vitrinite was relatively abundant in the shale, or the sample size was sufficiently large. Where sample size or amount of vitrinite was small, a marked difference in reflectance values of coal- and shale-derived vitrinite was noted. They attributed this difference to the disproportionate influence of recycled and weathered vitrinite in small samples or to samples having a low amount of indigenous vitrinite. Several major oil companies have informed us that within an interbedded sequence of coals, sandstones, shales, and limestones, fixed carbon determined from vitrinite reflectance can vary by as much as 5-10 percent between lithic types; the coals have the highest values and the carbonate rocks the lowest values. If this variation were solely a function of greater vitrinite abundance in rocks other than carbonate rocks, as suggested by Castaño and Sparks (1974), then the carbonate rocks, which generally have the least vitrinite, would yield the highest reflectance values because of their higher content of reworked and weathered vitrinite. Our own plots of carbonate and coal data as well as oil company data show the carbonates to have the lowest reflectance values. Correia's (1971) study of color alteration of palynomorphs from well samples in the Paris basin, shows that palynomorphs having the same burial history are less altered in carbonate rocks than in mudrocks, but that palynomorphs extracted from carbonate rocks have more uniform alteration patterns than palynomorphs from mudrocks. According to Timofeev and Bogolyubova (1963) and Chichua (1964), the reflectance and refractive index of vitrinite differ sharply from sandstones and mudstones; the mudstones have the highest values. Vitrinite reflectance may be affected by the permeability, porosity, and chemical composition, all of which affect thermal conductivity, of the host rock. Ammosov (1970) briefly discusses the effects of thermal conductivity on reflectance and presents a table of thermal conductivity coefficients for some of the common minerals, rocks, liquids, and gases.

Even coal beds show variation in reflectance. Vitrinite reflectance and thus percent fixed cabon are known to increase regularly from the center of a coal bed to its upper and lower contacts (Ammosov, 1970). Wilson (1961) reported this phenomenon as a common occurrence in the Arkoma basin of Oklahoma and Arkansas.

Because of the unknown effects of host-rock texture and composition on organic metamorphism, it seemed preferable to tie conodont CAI to percent fixed carbon determined from vitrinite derived from the same host rock and to limit our study to one reasonably homogeneous rock type-limestone.

\section{FIELD EVALUATION AND APPLICATION OF CONODONT CAI}

The Appalachian basin is an ideal area to field test the CAI of conodonts because most of the bedrock is of Paleozoic age. Igneous and metamorphic rocks of the Adirondacks (New York), Blue Ridge, and Piedmont terranes outline the basin on the north and east. Coastal Plain deposits overlap the basin on the south (in Alabama and Georgia) and the Nashville dome, Jessamine dome, and Cincinnati arch bound it on the west (fig. 13).

Alteration index maps were compiled for the Appalachian basin using our own collections and many specimens and samples kindly loaned to us by colleagues in universities, state surveys, and the petroleum industry. Almost all collections are from limestone; 66 of our 705 samples are from the subsurface. Conodonts from noncarbonate rocks were not used, so that variation in host-rock lithology could be neglected. To be sure, conodonts from other rock types also change color. Many bedding planes of black shale and siltstone from the Upper Devonian and Lower Mississippian Chattanooga Shale from the west half of the southern Appalachian basin contain conodonts, Sporangites (a megascopic palynomorph), and phosphatic brachiopods. All three organic elements are darker in slabs from more easterly outcrops, where overburden was greater in the Appalachian basin.

Because depth and duration of burial affect color alteration, we compiled conodont CAI isograd maps for three stratigraphic intervals: Ordovician, Silurian through Middle Devonian, and Upper Devonian through Pennsylvanian. These intervals were chosen mainly because they contain widespread marine carbonate rocks. 


\section{ORDOVICIAN CAI ISOGRAD MAP}

Figure 13 shows CAI isograds for mainly Middle Ordovician conodonts in the Appalachian basin. Analysis of the isograd map requires an isopach map of Middle Ordovician through Permian rocks. Such a map was compiled for the basin (not shown in this report) using data given in de Witt (1975), de Witt, Perry, and Wallace (1975), and Miller (1975). Throughout most of the basin, CAI isograd and isopach trends are conformable, especially in the west-

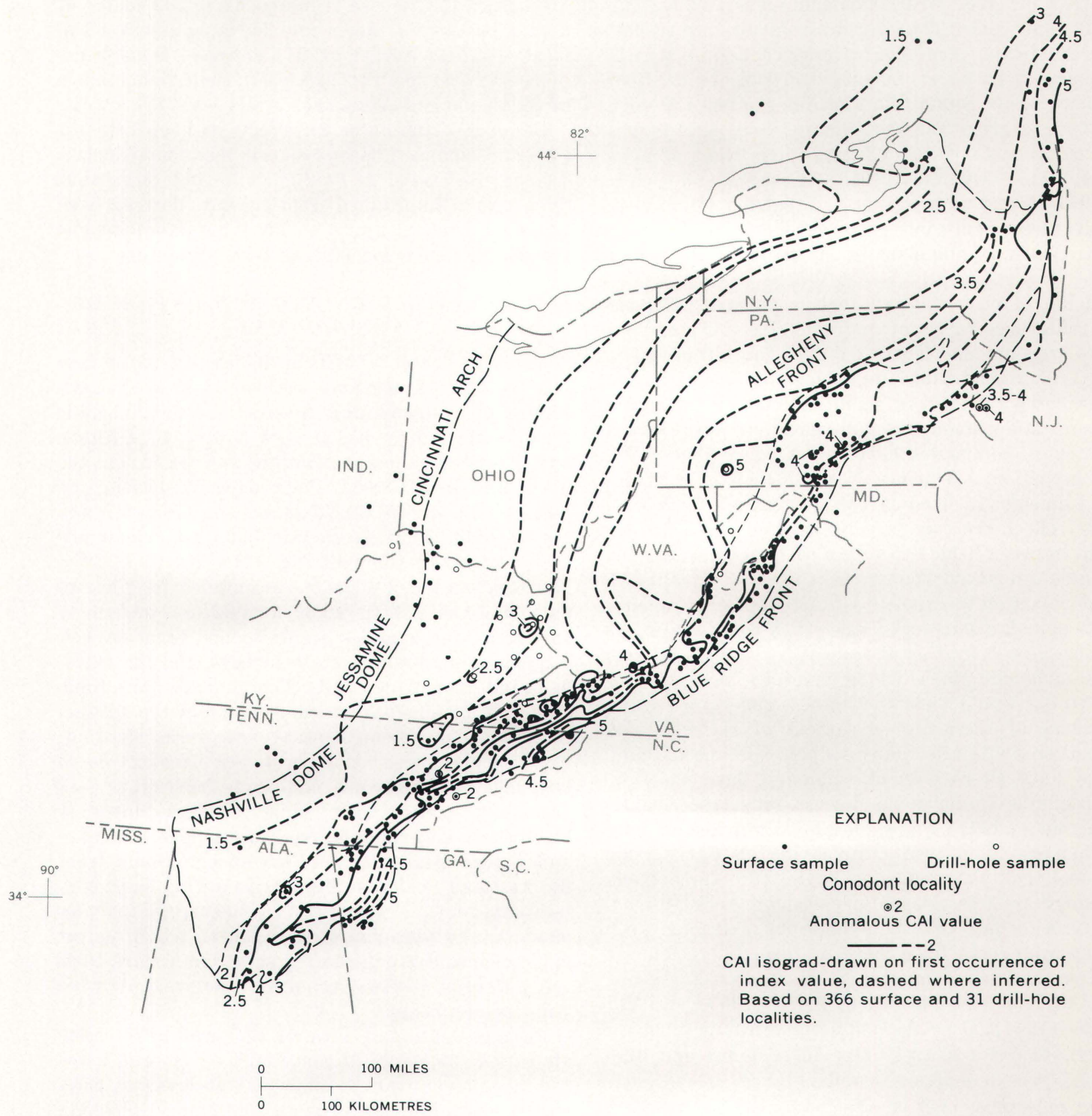

Figure 13.-Map showing CAI isograds in Ordovician rocks in the Appalachian basin. Conodonts from 60 Lower Ordovician, 308 Middle Ordovician, and 29 Upper Ordovician localities were indexed, for a total of 397 points. Wherever possible, early Middle Ordovician collections were used in order to provide as uniform a stratigraphic position as possible. 
ern and central parts of the basin where Ordovician rocks are mainly in the subsurface and deformation is minimum. The consistent westward bulge of Ordovician isograds in Pennsylvania reflects the composite effect of eastward-thickening Silurian, Devonian, Mississippian, Pennsylvanian, and Permian clastic wedges that are superimposed in that area. In most of Pennsylvania the original post-Ordovician overburden patterns are not as severely disrupted by late Paleozoic faulting as in areas south of central Virginia.

In western Pennsylvania, Ohio, West Virginia, and Kentucky, areas where most of the post-Ordovician rock sequence is still preserved, a comparison of Ordovician CAI isograds and Middle Ordovician to Permian isopachs show that: (1) conodont color alteration $(\mathrm{CAI}=1.5)$ begins at about 4,000 feet $(1,220 \mathrm{~m})$ of overburden; (2) CAI 1.5 persists from 4,000-8,000 feet $(1,220-2,440 \mathrm{~m})$ of overburden; (3) CAI 2 persists from about 8,000-12,000 feet $(2,440-3,660 \mathrm{~m})$ of overburden; (4) CAI 3 persists from about $12,000-18,000$ feet $(3,660-5,490$ $\mathrm{m})$ of overburden; (5) CAI 4 persists from about $18,000-25,000$ feet $(5,490-7,625 \mathrm{~m})$ of overburden; (6) CAI 5 begins at about 25,000 to 30,000 feet $(7,625-9,150 \mathrm{~m})$ of overburden. If the paleogeothermal gradient is assumed to have been similar to the present-day average geothermal gradient $\left(1^{\circ}\right.$ $\mathrm{C}$ per $100 \mathrm{ft}$ ) and to have been reasonably consistent throughout post-Ordovician time, then from the above data, the CAI 11/2-2 interval $(4,000-8,000$ ft overburden interval) equates to a temperature range of $60^{\circ}-100^{\circ} \mathrm{C}$. The experimental data (figs. $3,5)$ predict a $50^{\circ}-90^{\circ} \mathrm{C}$ range for the field of CAI $11 \%$ to 2 . CAI 5 begins at about 25,000 to 30,000 feet of overburden (or at a calculated temperature of $270^{\circ}-320^{\circ} \mathrm{C}$ ). The experimental data indicate $300^{\circ}$ $\mathrm{C}$ for the threshold of CAI 5. The close correlation of these temperature ranges indicates an apparent long-lived and consistent average geothermal gradient for a large part of the Appalachian basin. Moreover, the close correlation of these data also indicates that in the Appalachian basin, CAI values can be used to estimate overburden values, restore missing section, and reconstruct basin configuration.

An overview of figure 13 shows CAI 1 in areas having minimal burial history, which are along the western edge of the basin following the Nashville dome, Jessamine dome, and Cincinnati arch. Overburden and CAI increase eastward. Isograd trends and the strike of the overriding Blue Ridge-Piedmont terrane are discordant in Alabama, Georgia, Tennessee, and southern Virginia. In Georgia and
Tennessee, isograds parallel trends of major fold axes; both fold axes and isograds strike into the overthrust Blue Ridge-Piedmont terrane, indicating metamorphism preceeded thrusting. Thus we see preservation of prethrust carbonization patterns.

The circled localities (fig. 13) are anomalously low CAI values within higher index terrane. In Tennessee, conodonts from a window in the Great Smoky thrust sheet have a CAI of only 2. The two localities in New Jersey are in Taconic-type klippen whose present structural positions must therefore be the result of Appalachian thrusting. The anomalous areas have had a cooler thermal history than the surrounding terranes. These areas have farreaching paleogeographic and tectonic implications. In Tennessee and New Jersey, the conodonts are from rocks representing the eastern edge of the Appalachian basin, which were thrust westward during a late tectonic event and are now near the depocenter of the basin.

The CAI 3 high in cental northeast Alabama, may reflect an area of high heat flow, because it does not correlate with either isopach or structural trends. The westward bulge of the CAI 4 isograd in Highland County, Va., does correlate with an area of Cenozoic igneous activity.

Figure 14 shows the Virginia-West Virginia border area that includes the area of Cenozoic igneous activity. CAI isograds for Ordovician and Upper Silurian-Lower Devonian rocks have been superimposed on maximum isotherms for hot springs. The western bulge of the isograds on both maps can be explained by a higher than average heat flow associated with the known Eocene intrusions. Known overburden alone does not account for the high CAI values. Ideally, one would expect to see better closure of isograds around intrusions. The data points, however, were inadequate for more detailed contouring. The Ordovician CAI highs in the southern part of the map area showed no correlation with either isopach data or known igneous activity. The central West Virginia-Virginia border area, however, has long been known for its spas and thermal springs, and towns named Hot Springs, Warm Springs, and Mineral Springs dot the area. The hot spring isotherms show a high coincidence with Ordovician CAI highs. Thus, the isotherm configuration and the CAI highs may be related to a buried pluton from which the waters in the area derive their heat. Dennison and Johnson (1971) earlier proposed a buried felsic pluton to account for the hot spring activity, small Cenozoic igneous 


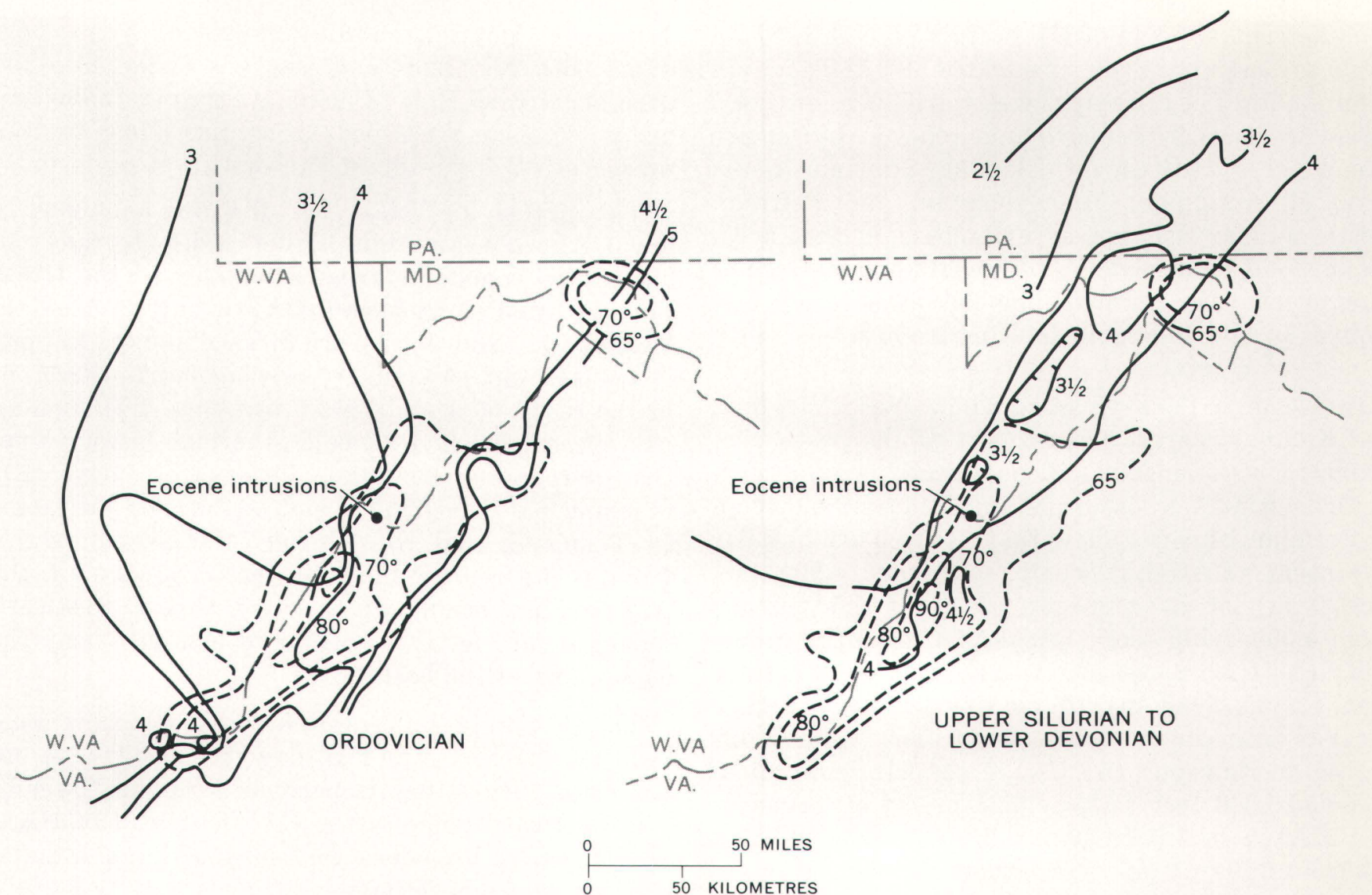

Figure 14.-Maps of the West Virginia-Virginia border area showing Ordovician and Upper Silurian to Lower Devonian CAI isograds (solid lines) superimposed on maximum isotherms, in degrees Fahrenheit, for hot springs (dashed lines). Isotherms from Dennison and Johnson (1971).

intrusive rocks, and large negative gravity anomaly in the Virginia-West Virginia border area.

Figure 15 shows the major faults in the Valley and Ridge province of Tennessee and a few localities for Middle and Late Ordovician conodonts. The lightest conodonts are from the Nashville dome area to the west. CAI 1 persists into the Pine Mountain overthrust block and then conodonts become progressively darker through more easterly thrust belts-from the Sequatchie to the Dumplin Valley. Conodonts from the Tuckaleechee Cove window in the Great Smoky thrust sheet, however, have a CAI of only 2, indicating that these rocks could not have been buried as deeply or have reached the same degree of thermal maturity as correlative rocks, 10 15 miles $(16-24 \mathrm{~km})$ to the west, which are exactly the same age but have conodonts with a CAI of 4 (fig. 15).

\section{SILURIAN THROUGH MIDDLE DEVONIAN GAI ISOGRAD MAP}

Almost all points shown on the map (fig. 16) are for uppermost Silurian and lowermost Devonian limestones. Early Devonian conodonts near the Allegheny front in Pennsylvania have CAI values of 2.5 to 3 . The 4 index first occurs 30 miles $(48 \mathrm{~km})$ across strike to the east. The 4 isograd on this map is considerably east of the 4 isograd on the Ordovician map (compare figs. 13 and 16). Along the eastern edge of the Valley and Ridge province in Pennsylvania, Early Devonian conodonts have CAI values of 4.5. Vitrinite particles from the same rocks have reflectance values of +3.5 , indicating greater than 95 percent fixed carbon (fig. 16, values adjacent to dots). Pennsylvanian coals immediately to the west, have 91-96 percent fixed carbon (Wood and others, 1969). An area of high CAI 4 occurs in West Virginia and Maryland. Fixed carbon values of 88-90 within the high, determined using vitrinite from the same samples as the conodonts, corroborate this high level of organic metamorphism.

\section{UPPER DEVONIAN THROUGH MISSISSIPPIAN CAI ISOGRAD MAP}

Figure 17 shows Upper Devonian through Mississippian localities and isograds. Pennsylvanian 


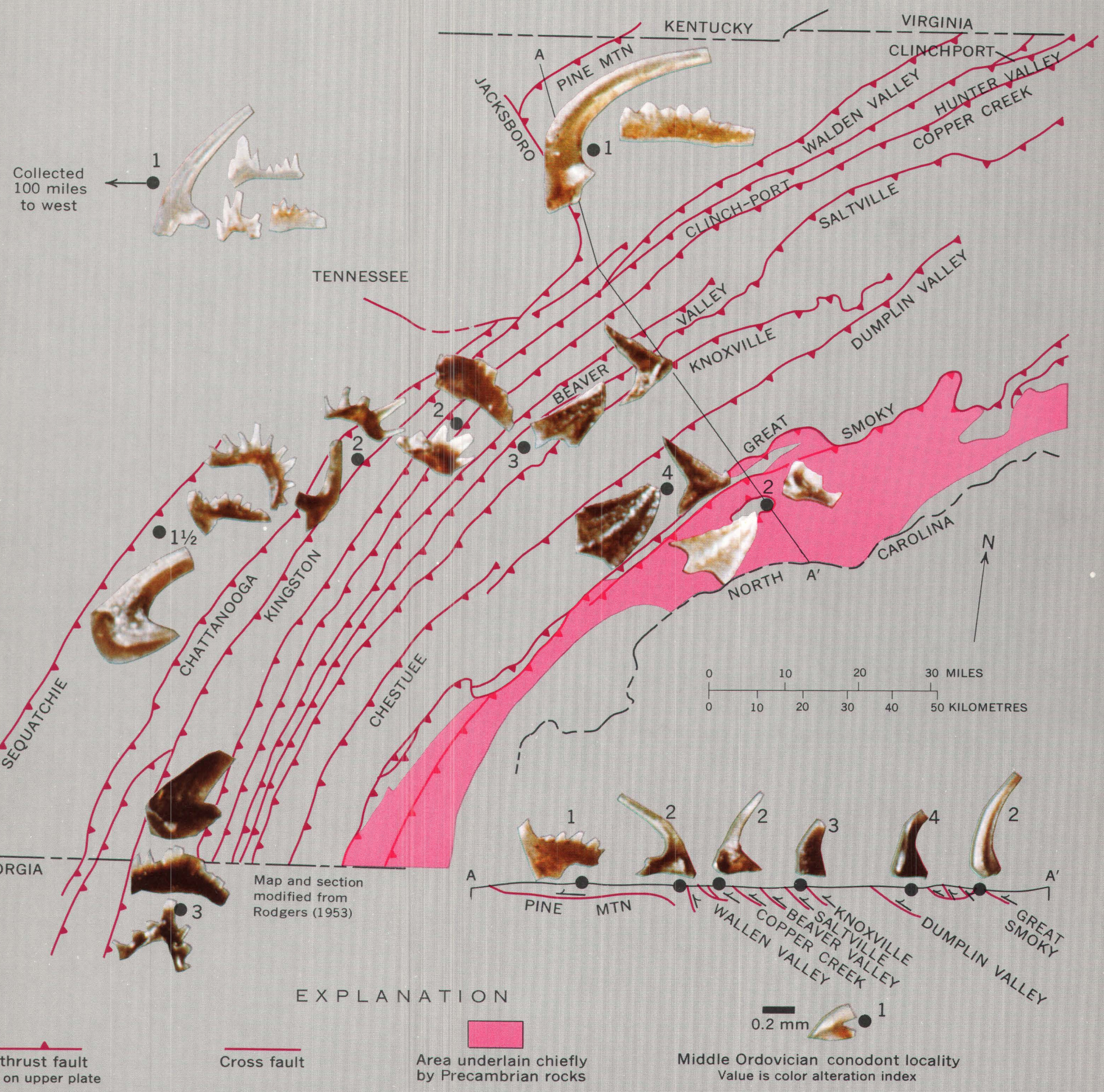

FiguRE 15.-Map showing major thrust faults and some localities for Middle and Late Ordovician conodonts from eastern Tennessee. 


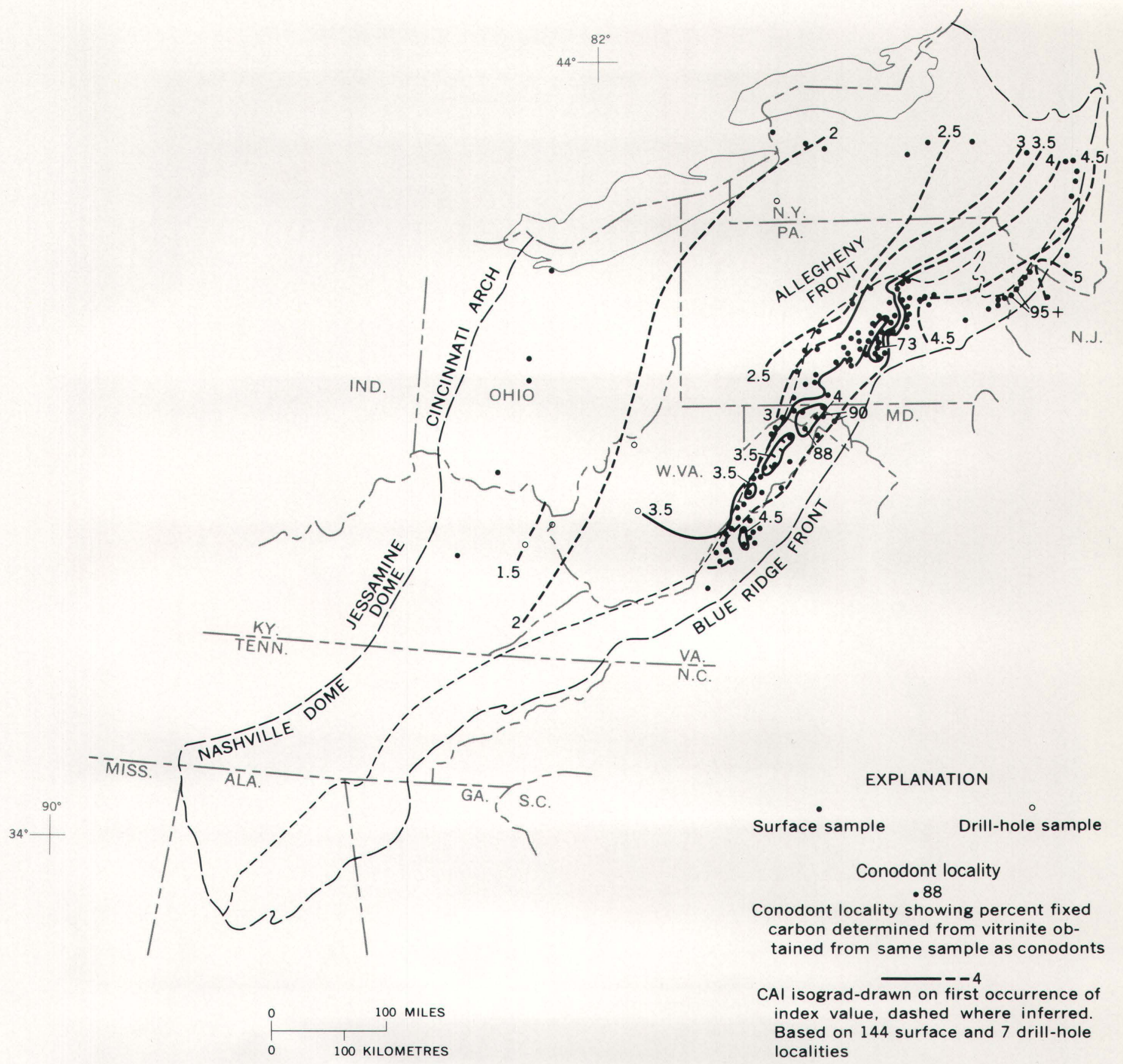

Figure 16.-Map showing CAI isograds for Silurian through Middle Devonian rocks in the Appalachian basin. Conodonts from 43 Silurian and 108 Lower and Middle Devonian localities were indexed for a total of 151 points. Isograds do not extend south of southern Virginia because carbonate rocks of this age are generally absent in the outcrop belt.

A Devonian through Permian isopach map was compiled for the Appalachian basin (not shown is this report) using data from de Witt (1975) and de Witt, Perry, and Wallace (1975). Silurian to Middle Devonian CAI isograds and Devonian to Permian isopachs show good correlation. The westward extension of all isograds in Pennsylvania correspond to west-trending, eastward-thickening Upper Devonian, Mississippian, and Pennsylvanian clastic wedges. Comparison of isopachs and isograds in the north-central part of the Appalachian basin show that CAI 2 persists from 6,000 to 12,000 feet $(1,830-3,660 \mathrm{~m})$ of overburden and CAI 4 persists from about 22,000 to $+26,000$ feet $(6,710-7,930 \mathrm{~m})$. 


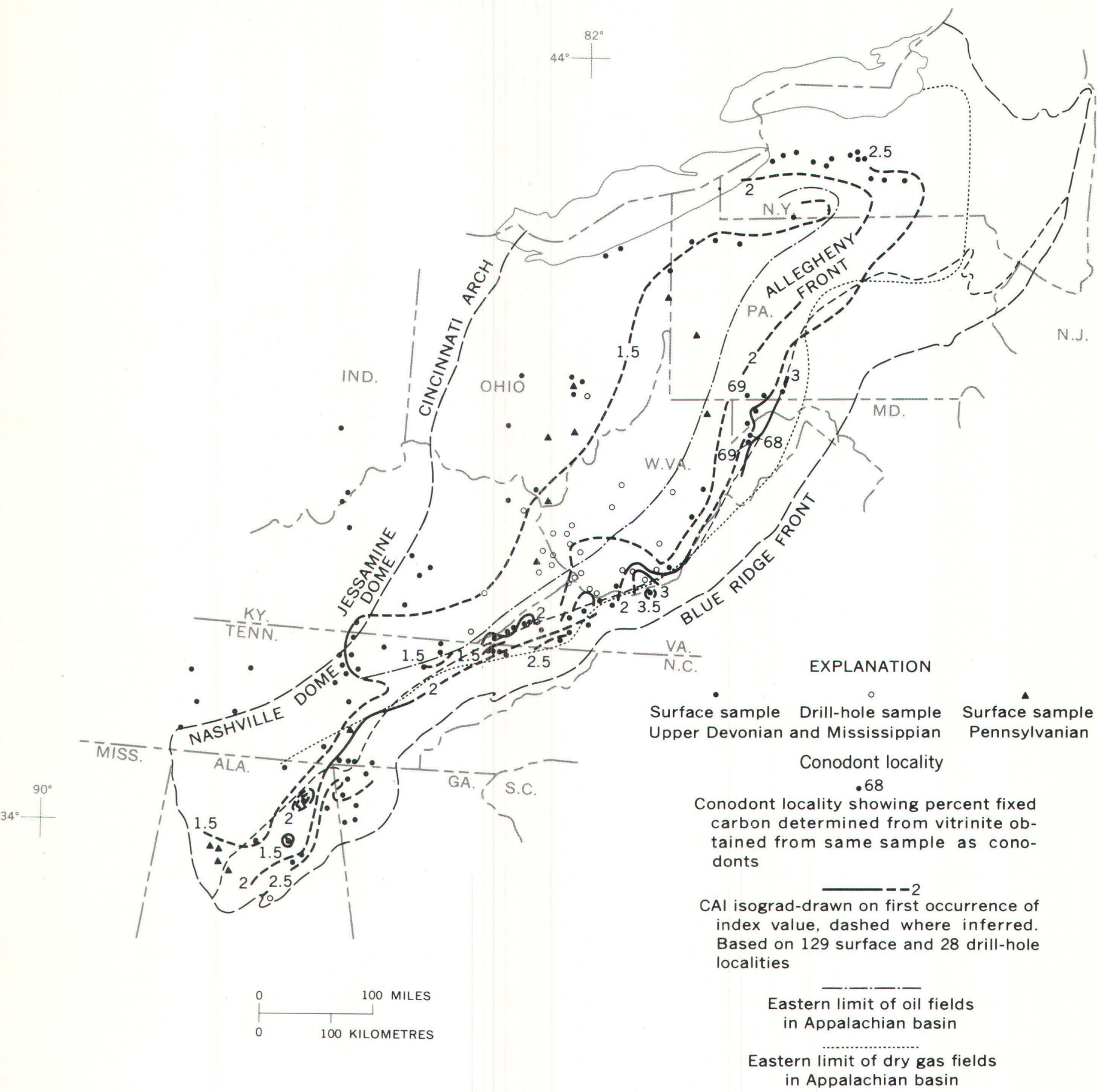

FIgURE 17.-Map showing CAI isograds for Upper Devonian through Mississippian rocks and the eastern limit of oil and gas fields in the Appalachian basin (from Vlissides and Quirin, 1964). Pennsylvanian localities are shown but have not been contoured. Conodonts from 143 Upper Devonian through Mississippian and 14 Pennsylvanian localities were indexed.

localities are shown separately. Mississippian conodonts along the Allegheny front in the north half of the basin generally have indexes of 2.5 to 3 , whereas in the same area, Ordovician conodonts have an index of 4 , showing increase in index with increase in depth of burial. An area of higher index terrane extends westward into part of the Pine
Mountain, overthrust block. In this area, where data are closely spaced, isograds follow the fold patterns of the outcrop belts, indicating preservation of pre-orogenic CAI patterns.

Figure 18 is an enlargement of a map of part of the southern Appalachian basin showing CAI isograds for Upper Mississippian limestones and iso- 


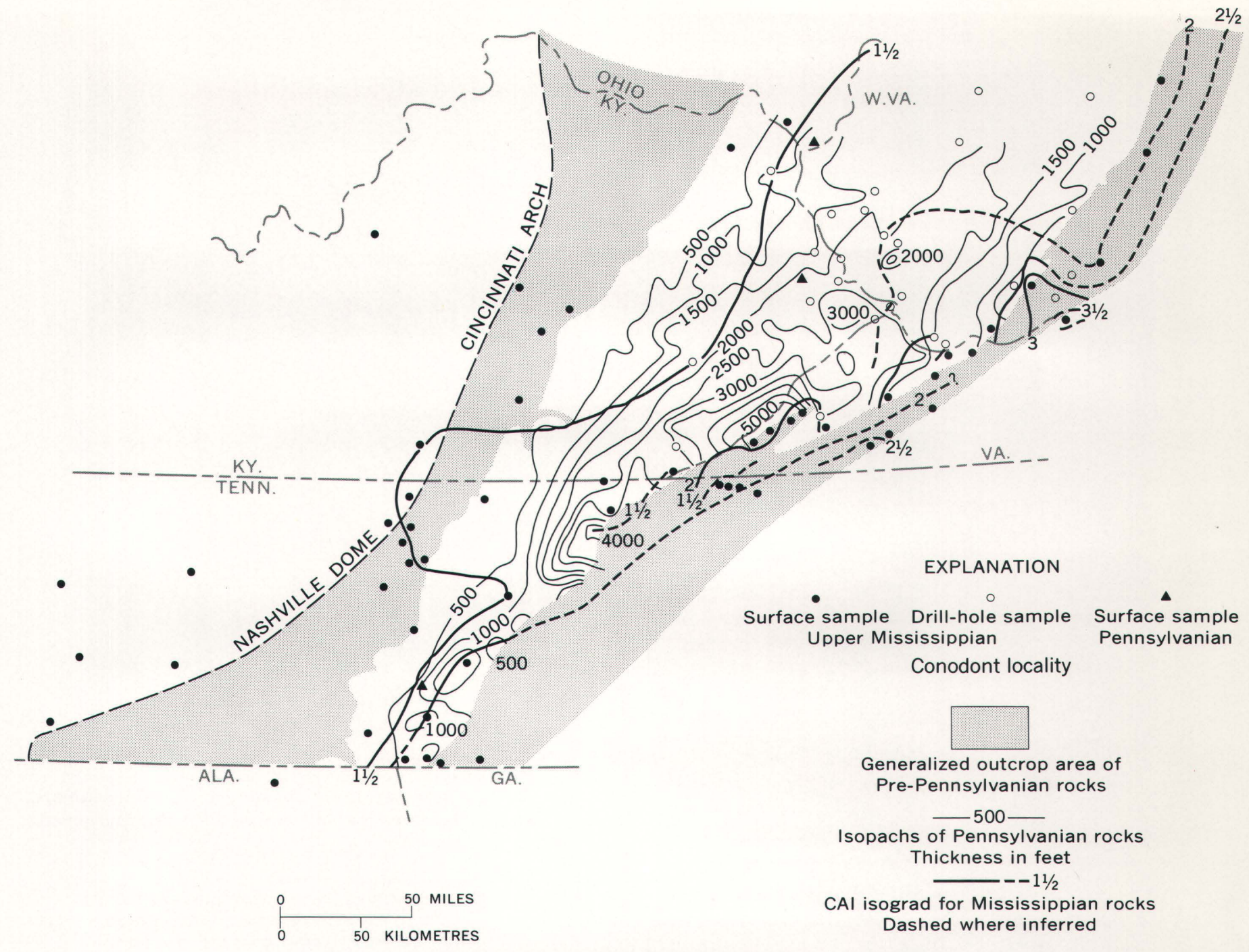

FIgURE 18.-Map of part of the Appalachian basin showing Upper Mississippian CAI isograds superimposed on isopachs for Pennsylvanian rocks (from de Witt, 1975, sheet 2).

pachs for Pennsylvanian rocks. The Pennsylvanian rocks probably represent most of the post-Missisippian deposits because younger deposits were very thin or absent. The westward projecting lobe of the 1.5 isograd at the Kentucky-Tennessee border may conform to a lobe of Pennsylvanian rocks that at one time extended farther westward. Significantly the 1.5 isograd outlines an area of oil and gas production from Mississippian rocks in Tennessee and Kentucky (de Witt, 1975, sheet 4). The 2 isograd in West Virginia encompasses the 2,500-foot-thick outlier of Pennsylvanian rock that must have at one time been part of a much thicker continuous northwest-trending clastic wedge. The 5,000-footthick lobe of Pennsylvanian rock in southern Virginia is not noticeably reflected in the CAI isograds because we have no subsurface data in that area.
The northwest-trending area of CAI 2 to 3.5 in southeast West Virginia coincides with anomalous Ordovician CAI highs (figs. 13, 14). These highs probably result from the high heat flow associated with a buried pluton.

\section{CAI ISOGRADS PROVIDE CUTOFFS FOR OCCURRENCE OF HYDROCARBONS}

CAI isograds for Ordovician rocks and the eastern limit of oil and gas fields (Vlissides and Quirin, 1964) producing from Ordovician rocks in the Appalachian basin are shown in figure 19. The oil fields are west of the 2 isograd in surface rocks and gas production is in areas where surface rocks have CAI values of 2 to 3 .

Isograds for Silurian through Middle Devonian rocks and the eastern limit of oil and gas fields in 


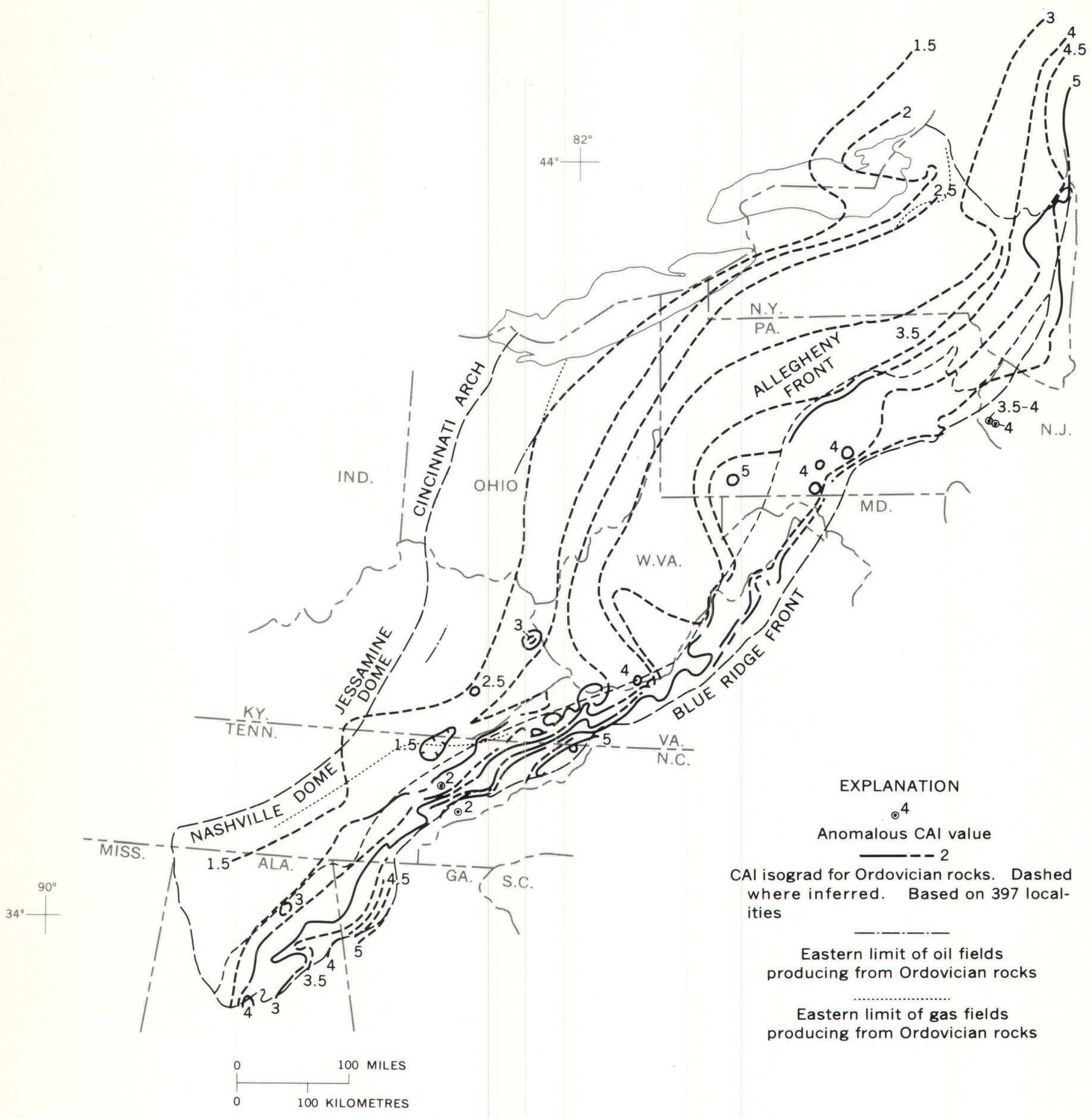

Figure 19.-Map showing CAI isograds for Ordovician rocks and the eastern limit of oil and gas fields (from Vlissides and Quirin, 1964) in these same rocks in the Appalachian basin. Circled localities are areas of low CAI within higher index terrane.

these same rocks are shown in figure 20. The oil fields are once again west of the 2 isograd in surface rocks, but gas production extends into areas where surface rocks have CAI values as high as 4 .

Figure 17 shows that an alteration index of 2 appears to be just east of the upper thermal limit of known oil and condensate production. A CAI of 1.5 correlates with a fixed carbon range of $60-65$ percent and with a vitrinite reflectance range of $0.7-$ 0.85 (fig. 11). Most reports give 0.8 reflectance and 62-65 percent fixed carbon as the cutoff for most commercial oil and condensate production 


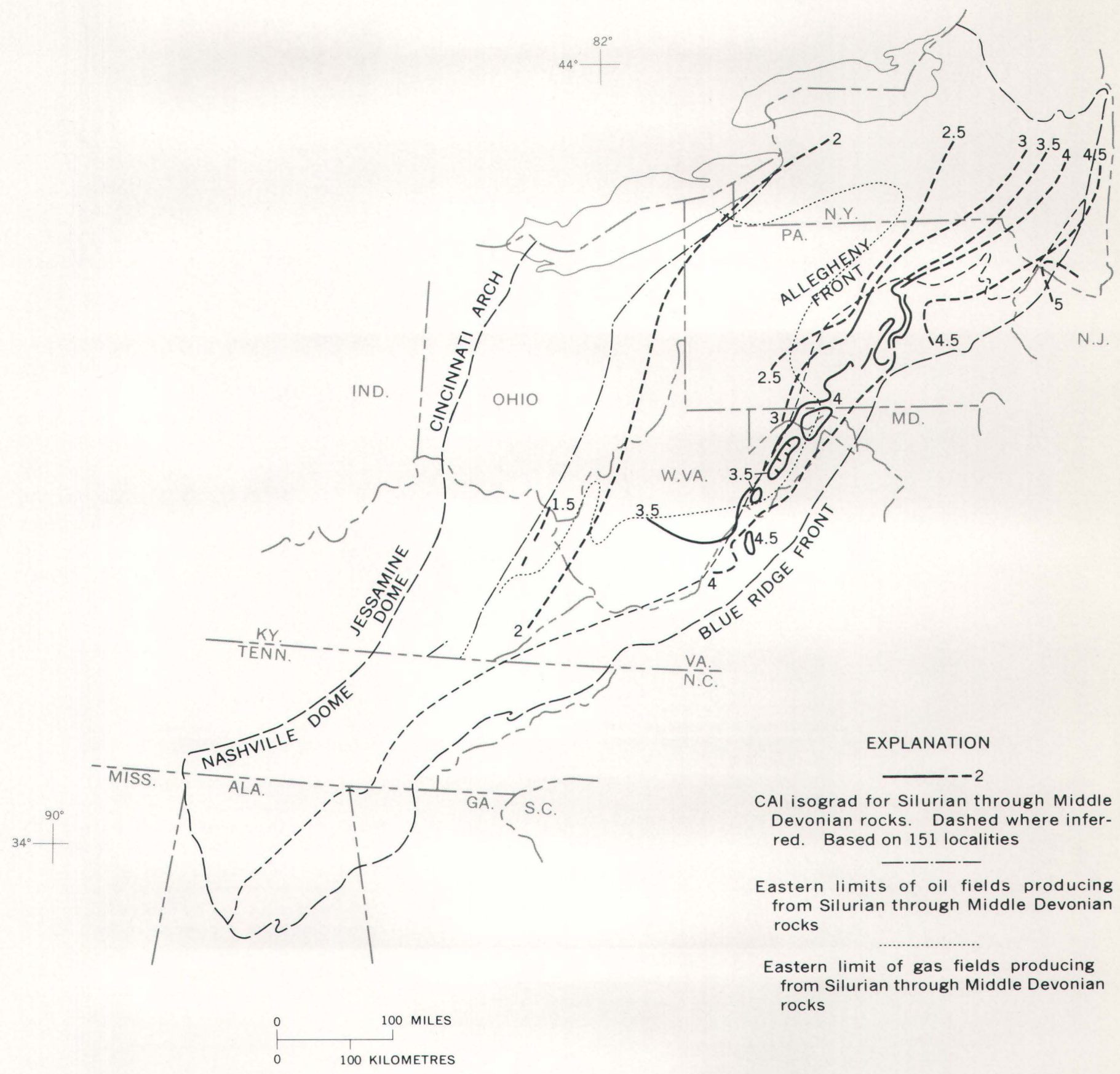

Figure 20.--Map showing CAI isograds for Silurian through Middle Devonian rocks and the eastern limit of oil and gas fields (from Vlissides and Quirin, 1964, and de Witt, Perry, and Wallace, 1975) in these same rocks in the Appalachian basin.

(Bostick and Damberger, 1971, table 1). It is important to note that cutoffs for oil production for different stratigraphic intervals are not coincident geographically. In Pennsylvania, dry gas has been produced from strata containing coal beds and dispersed coaly particles in an area where surface rocks have fixed carbon values of 90 percent or higher. The upper thermal limit for dry gas production appears to be near an index of 4 to 4.5. Interestingly, this may also be near the thermal threshold for the development of slaty cleavage (Epstein, 1974). A CAI of 4-4.5 correlates with a fixed carbon range 
of 84-95 percent and a vitrinite reflectance range of 0.95-3.6 (fig. 11). Bostick and Damberger (1971, table 1) show 95 percent fixed carbon and a reflectance of 3.0 as the limit for commercial dry gas production.

The maps indicate that the best potential for oil or gas production is in the western part of the southern Appalachian basin and the best potential for gas production is in the eastern part of the southern Appalachian basin.

Some possibilities for gas exist beneath the leading edge of the Blue Ridge-Piedmont terrane as indicated by thermal lows in windows and klippen in that area (fig. 19).

\section{CONCLUSIONS}

The color alteration index (CAI) of conodonts is a valuable tool for assessing organic metamorphism because:

1. It is a rapid and inexpensive method requiring only standard laboratory techniques and a binocular microscope.

2. A color chart can be used for index determination or a set of standards can be assembled from field collections or cooked in the laboratory. Thus standards can be easily assembled and reproduced.

3. Conodont color alteration begins near the upper thermal limit for many palynomorphs. The CAI of conodonts provides thermal cutoffs for oil, condensate, and dry gas production.

4. The CAI of conodonts is applicable to rocks as old as Cambrian, whereas reflectance techniques for vitrinite cannot be used for pre-Devonian rocks.

5. AND MOST IMPORTANT-Conodonts are most abundant and most easily concentrated from marine carbonate rocks in which palynomorphs are generally poorly preserved and in which vitrinite is least abundant and often absent.

\section{ACKNOWLEDGMENTS}

We wish to thank P. R. Rose, U.S. Geological Survey, for his enthusiastic support of our study and for seeing its potential. C. W. Cressler, U.S. Geo-logical Survey, was invaluable in locating all the outcrops of fresh Paleozoic carbonate rocks in northwest Georgia. Thanks are due the Georgia Geological Survey for field support in the largest state east of the Mississippi. Many colleagues in universities, state surveys, and the petroleum industry provided us with specimens and (or) carbonate samples from the Appalachian basin. They include,
S. G. Barnett, III, SUNY, Plattsburg, N.Y.; P. J. Brown, Columbia Gas Transmission Corp.; J. A. Drahovzal, Alabama Geol. Survey; P. W. Goodwin, Temple Univ.; G. K. Merrill, The College of Charleston; W. C. Sweet, The Ohio State Univ.; C. G. Tillman, Virginia Polytechnic Inst.; C. C. Rust, General Crude Corp.; Shell Canada Ltd.; Amoco Production Co.; Columbia Gas Transmission Corp.; we hope we remembered them all.

N. H. Bostick and H. H. Damberger, Illinois Geol. Survey, J. A. Clendening, Amoco Production Co., F. L. Staplin, Imperial Oil Ltd., and Logan Urban, Phillips Petroleum, were exceedingly helpful in discussing the technology and application of other organic indexes with rank amateurs. J. A. Clendening also provided us with the palynomorph translucency determinations.

We are deeply indebted to P. J. Brown, Columbia Gas Transmission Corp., for providing us with numerous well samples from the central Appalachian basin. Special thanks are also due S. M. Bergström, The Ohio State Univ., for providing us with access to his numerous Appalachian basin collections and to the collections of the Orton Museum. We thank him too for the use of office space and for the conodont-rich rock samples from which we obtained all our experimental specimens. Charles Sandberg, U.S. Geological Survey, reviewed the manuscript and provided several helpful suggestions and criticisms.

\section{REFERENCES CITED}

Abelson, P. H., 1954, Paleobiochemistry, in Abelson, P. H., Annual report of the director of the Geophysical Laboratory: Carnegie Inst. Washington Year Book no. 53, 1953-54, p. 97-101.

Ammosov, I. I., 1970, Stages of lithification of sedimentary rocks: Compte Rendu, Sixième Congrès Internat. de Stratigraphie et de Géologie du Carbonifère, Sept. 1967, Sheffield, v. 2, p. 403-415.

Ashley, G. W., 1928, Bituminous coal fields of Pennsylvania; introductory volume, part 1 , general information on coal: Pennsylvania Geol. Survey, 4th ser., Bull. M6, pt. 1, 241 p.

Bergström, S. M., and Sweet, W. C., 1966, Conodonts from the Lexington Limestone (Middle Ordovician) of Kentucky, and its lateral equivalents in Ohio and Indiana: Bulls. Am. Paleontology, v. 50, no. 229, p. 271-441.

Bostick, N. H., 1970, Thermal alteration of clastic organic particles (Phytoclasts) as an indicator of contact and burial metamorphim in sedimentary rocks: Palo Alto, Calif., Stanford Univ., Ph.D. dissertion, 220 p.

- 1973, Time as a factor in thermal metamorphism of phytoclasts (coaly particles): Compte Rendu, Septième Congrès Internat. de Stratigraphie et de Géologie du Carbonifère, August 1971, Krefeld, v. 2, p. 183-193.

- 1974, Phytoclasts as indicators of thermal metamorphism, Franciscan assemblage and Great Valley sequence 
(upper Mesozoic), California, in Dutcher, R. R., and others, eds., Carbonaceous materials as indicators of metamorphism: Geol. Soc. America Spec. Paper 153, p. 1-17.

Bostick, N. H., and Damberger, H. H., 1971, The carbon ratio rule and petroleum potential in NPC Region 9: Illinois Petroleum, v. 95, p. 142-151.

Castaño, J. R., and Sparks, D. M., 1974, Interpretation of vitrinite reflectance measurements in sedimentary rocks and determination of burial history using vitrinite reflectance and authigenic minerals, in Dutcher, R. R., and others, eds., Carbonaceous materials as indicators of metamorphism: Geol. Soc. America Spec. Paper 153, p. $31-52$.

Chichua, B. K., 1964, On the study of the initial metamorphism of sedimentary rock in connection with their petroleum prospects [in Russian]: Azerbaydzhan neft. Khoz., no. 7.

Correia, Michel, 1971, Diagenesis of sporopollenin and other comparable organic substances: application of hydrocarbon research, in Brooks, J., and others, eds., Spcropollenin: London, Academic Press, p. 569-620.

Damberger, H. H., 1974, Coalification patterns of Pennsylvanian coal basins of the eastern United States, in Dutcher, R. R., and others, eds., Carbonaceous materials as indicators of metamorphism: Geol. Soc. America Spec. Paper 153, p. 53-74.

Dennison, J. M., and Johnson, R. W., Jr., 1971, Tertiary intrusions and associated phenomena near the thirty-eighth parallel fracture zone in Virginia and West Virginia: Geol. Soc. America Bull., v. 82, p. 501-508.

de Witt, Wallace, Jr., 1975, Oil and gas data from the upper Paleozoic rocks in the Appalachian basin: U.S. Geol. Misc. Geol. Inv. Map I-917 A, 4 sheets, scale 1:2,500,000.

de Witt, Wallace, Jr., Perry, W. J., Jr., and Wallace, L. G.. 1975, Oil and gas data from the Devonian and Silurian rocks in the Appalachian basin: U.S. Geol. Survey Misc. Geol. Inv. Map I-917 B, 4 sheets, scale 1:2,500,000.

Eby, J. B., 1923, The possibilities of oil and gas in southwest Virginia as inferred from isocarbs: Am. Assoc. Petroleum Geologists Bull., v. 7, no. 4, p. 421-426.

Ellison, Samuel, 1944, The composition of conodonts: Jour. Paleontology, v. 18, no. 2, p. 133-140.

Epstein, A. G., 1975, Conodont color alteration-A geothermometer and index of organic metamorphism [abs.? : Reservoir, v. 2, no. 6, p. 1-2.

Epstein, A. G., Epstein, J. B., and Harris, L. D., 1974, Incipient metamorphism, structural anomalies, and oil and gas potential in the Appalachian basin determined from conodont color: Geol. Soc. America Abstracts with Programs, Ann. Mtg., 1974, Miami Beach, Fla., v. 6, no. 7, p. 723-724.

1975a, Conodont color alteration-an index to diagenesis of organic matter: Am. Assoc. Petroleum Geologists and Soc. Econ. Paleontologists and Mineralogists Ann. Mtg. Abstracts, v. 2, April 1975, Dallas, Tex., p. 21-22.

1975 b, Conodont color alteration-an index to organic metamorphism: U.S. Geol. Survey open-file rent. 75-379, $54 \mathrm{p}$.

Epstein, J. B., 1974, Metamorphic origin of slatv cleavage in eastern Pennsylvania: Geol. Soc. America Abstracts with Programs, Ann. Mtg., 1974, Miami Beach, Fla., v. 6, no, 7, p. 724 .
Gutjahr, C. C. M., 1966, Carbonization measurements of pollen-grains and spores and their application: Leidse Geol. Meded., v. 38, p. 1-29.

Hacquebard, P. A., and Donaldson, J. R., 1970, Coal metamorphism and hydrocarbon potential in the upper Paleozoic of the Atlantic Provinces, Canada: Canadian Jour. Earth Sci., v. 7, p. 1139-1163.

- 1974, Rank studies in coals in the Rocky Mountains and inner foothills belt, Canada, in Dutcher, R. R., and others, eds., Carbonaceous materials as indicators of metamorphism: Geol. Soc. America Spec. Paper 153, p. $75-94$.

Hood, A., Gutjahr, C. C. M., and Heacock, R. L., 1975, Organic metamorphism and the generation of petroleum: Am. Assoc. Petroleum Geologists Bull., v. 59, no. 6, p. 986-996.

Huck, G., and Patteisky, K. M., 1964, Inkohlungsreaktionen unter Druck: Fortschr. Geologie Rheinland u. Westfalen, v. $12,551 \mathrm{p}$.

Lindström, Maurits, 1964, Conodonts: New York, Elsevier Publishing Co., 196 p.

McIntyre, D. J., 1972, Effect of experimental metamorphism on pollen in a lignite: Geoscience and Man, v. 4, Oct. 1, 1972, p. 111-117.

Martin, R. L., Winters, J. C., and Williams, J. A., 1964, Composition of crude oils by gas chromatography: geological significance of hydrocarbon distributions: 6th World Petroleum Cong. Proc., 1963, Frankfurt/Main, sec. 5, p. 231-260.

Meyer, R. F., and Edgerton, C. D., Jr., 1968, Petroleum and natural gas, in U.S. Geological Survey and U.S. Bureau of Mines, Mineral resources of the Appalachian region: U.S. Geol. Survey Prof. Paper 580, p. 145-163.

Miller, R. L., 1975, Oil and gas data from the Upper and Middle Ordovician rocks in the Appalachian basin: U.S. Geol. Survey Misc. Geol. Inv. Map I-917 C, 2 sheets, scale $1: 2,500,000$.

Munsell Color Company, 1971, Munsell soil color charts: Baltimore, Md., Munsell Color Company, Inc.

Oliver, W. A., Jr., and others, 1971, Isopach and lithofacies maps of the Devonian in the Appalachian basin: Pennsylvania Geol. Survey Prog. Rept. 182, 6 sheets.

Patteisky, K. M., Teichmüller, Marlies, and Teichmüller, Rolf, 1962, Das Inkohlungsbild des Steinkohlengebirges an Rhein und Ruhr, dargestellt im Niveau von Flöz Sonnenschein: Fortschr. Geologie Rheinland u. Westfalen, v. 3, no. 2, p. $687-700$.

Pietzner, Horst, Vahl, Johanna, Werner, Hans, and Ziegler, Willi, 1968, Zur chemischen Zusammensetzung und Mikromorphologie der Conodonten: Palaeontographica, v. 128, pt. A, p. 115-152.

Philippi, G. T. 1965, On the depth, time and mechanism of petroleum generation: Geochim. et Cosmochim. Acta, v. 29, p. 1021-1049.

Postley, O. C., 1935, Natural gas developments and possibilities east of the main oil and gas fields of Appalachian region: Am. Assoc. Petroleum Geologists Bull., v. 19, no. 6. p. $853-875$.

Rodgers, John, 1953, Geologic map of East Tennessee with explanatory text: Tenn. Dept. Conserv. Div. Geology Bull. 58, pt. 2, 168 p. 
Schapiro, N., and Gray, R. J., 1966, Physical variations in highly metamorphosed Antarctic coals, in Given, Peter, chm., Coal Science-Advances in Chemistry Series 55: Washington, D.C., Am. Chem. Soc., p. 196-210.

Staplin, F. L., 1969, Sedimentary organic matter, organic metamorphism, and oil and gas occurrence: Bull. Canadian Petroleum Geology, v. 17, no. 1, p. 47-66.

Staplin, F. L. Bailey, N. J. L., Pocock, S. A. J., and Evans, C. R., in press, Diagenesis and metamorphism of sedimentary organic matter, in Am. Assoc. Petroleum Geologists Symposium.

Sweet, W. C., and Bergström, S. M., eds., 1971, Symposium on conodont biostratigraphy: Geol. Soc. America Mem. 127,499 p.

Teichmüller, Marlies, and Teichmüller, Rolf, 1968, Geological aspects of coal metamorphism, in Murchison, Duncan, and Westoll, T. S., eds., Coal and coal-bearing strata: New York, Elsevier Publishing Co., p. 233-267.
Timofeev, P. P., and Bogolyubova, L. I., 1963, Peculiar features of vitrain carbonification in rocks and coals of the Angren brown coal deposit [in Russian]: Akad. Nauk SSSR Doklady, v. 151, no. 4, p. 938-941.

Vlissides, S. D., and Quirin, R. A., 1964, Oil and gas fields of the United States exclusive of Alaska and Hawaii: Washington, D.C., U.S. Geol. Survey, scale 1:2,500,000.

White, David, 1915, Some relations in origin between coal and petroleum: Washington Acad. Sci. Jour., v. 5, no. 6, p. 189-212.

Wilson, L. R., 1961, Palynological fossil response to low-grade metamorphism in Arkoma basin: Tulsa Geol. Soc. Digest, v. 29 , p. $131-140$.

Wood, G. H., Jr., Trexler, J. P., and Kehn, T. M., 1969, Geology of the west-central part of the Southern Anthracite field and adjoining areas, Pennsylvania: U.S. Geol. Survey Prof. Paper 602, 150 p. 